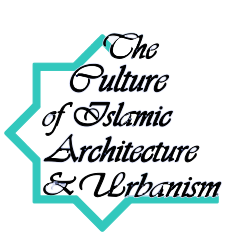

\title{
Re-evaluation of the Patterns and Practices of Contextual Architecture in Islamic Cities in the Age of Globalization
}

\author{
Erfan Khasm Afkan Nezam ${ }^{1}$, Fereshte Navidi Majd ${ }^{2}$, Babak Fadavi Anbiayee ${ }^{3}$ \\ $1 \mathrm{PhD}$ Candidate in Architecture, Faculty of Art and Architecture, Islamic Azad University, South Tehran Branch, Tehran, Iran. \\ 2 Assistant Professor, Faculty of Art and Architecture, Islamic Azad University, Islamshahr Branch, Islamshahr, Iran. \\ 3 Assistant Professor, Faculty of Art and Architecture, Islamic Azad University, Islamshahr Branch, Islamshahr, Iran. \\ (Received 31 Jul 2019, Accepted 24 Dec 2019)
}

In the world architecture literature, Islamic architecture features as an important and noteworthy historical tradition. This tradition is regarded far beyond a purely historical tradition by Iranians. Iranian architecture represents a manifestation of unity in plurality and an attempt to achieve unity in the plurality world through uniting the opponents via an order; this kind of architecture, is considered as a part of architectural identity in Islamic Iran. In the Iranian-Islamic culture, architect as a devotee worshiper and bystander in this world, would design and implement the capsule of human living in harmony with the facts of the universe and not for the sake of showing off, as he relied on a power beyond human will and control. It is not through wealth, dexterity and expertise but through the amount of transparency, capability and requirement is able to get a glimpse of the infinite truth and manifest it in his work, with respect to the physical, historical, climato-geographical and socio-cultural contexts of the architectural context. "Islamic architecture", unlike Renaissance architecture, does not make man aware of the function of each part of building, as this is a mixing between two realms of reality from the Islamic view point and means lack of intellectual honesty. Accordingly, it is through considering "identity" in the context that brings plurality close to "diversity," and it is the diversity that makes life attractive and beautiful. Nowadays, religion and religious teachings have been however marginalized in the body of the contemporary Iranian city, resulting in a body shaped entirely based on the patterns of modernity (especially contemporary western civilization) or globalization. This, and the available literature on contextualism, warranted a study on this field of Islamic view and Muslim thinkers. The present study consists of two parts: in the first part, using the "meta-analysis" method, addresses the previous works on the "Islamic city" and its subsets as well as "contextualism" in the Islamic thought and the available literature of eastern thinkers. In the second, the components are analyzed based on the types of "contextualism" in the contemporary architecture before the "model of Islamic view on context" is presented in a diagram. Based on the results, considering the design processes and patterns practiced and formed by "experienced and thoughtful architects" represents a way to grasp socio-cultural roots of contemporary society. Because, these projects adhere to simple and consistent patterns that stem from the culture, beliefs, nature and lifestyles of the community, and the conversion of these factors into architectural patterns should be explained to the public and should be acted in a way that the simple and consistent principles become context of the architectural designs spontaneously. This study aimed at obtaining a single source, guiding principles and executive guidelines to be used by designers in designing new buildings in the valuable contexts of Islamic cities; as "future shapes and patterns will be born in relation to the past and the persistent and repeating past principles will take on their new form with new experience and insight."

Keyword: Islamic city, Responses architecture, Reverence, Contextualism pattern, Context.

\footnotetext{
*Corresponding author. E-mail: erfannezam@yahoo.com 


\section{بازشناسى الكوها و رويههاى معمارى زمينهَّرا در انديشه و شهرهاى اسلامى در عصر جهانى وسازى معماري}

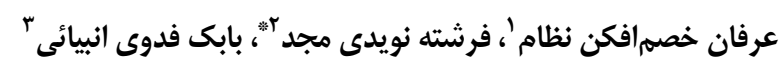

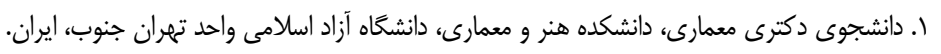

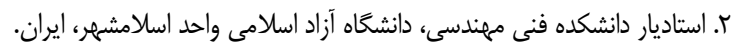

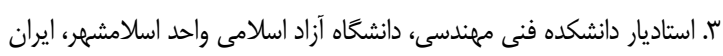

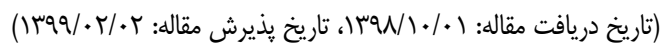

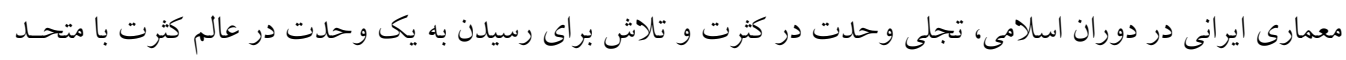

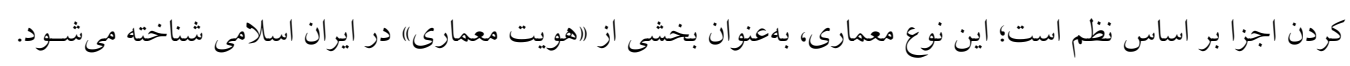

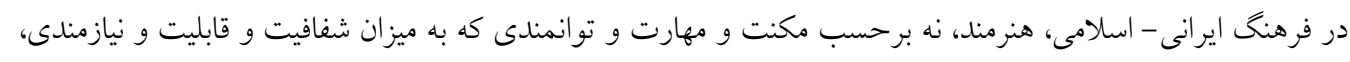

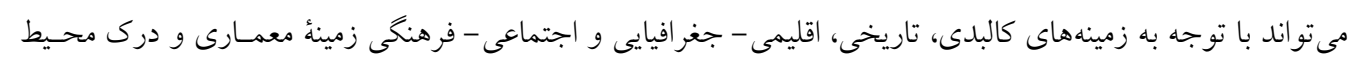

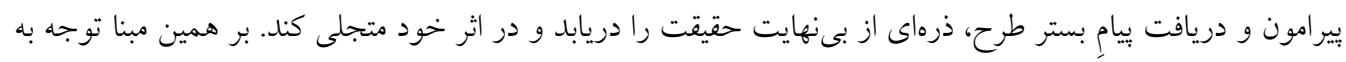

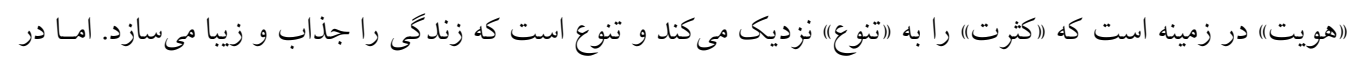

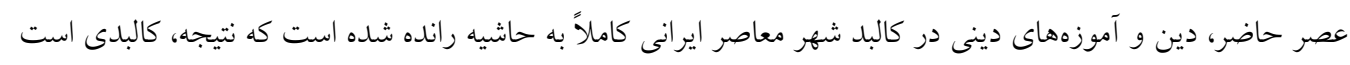

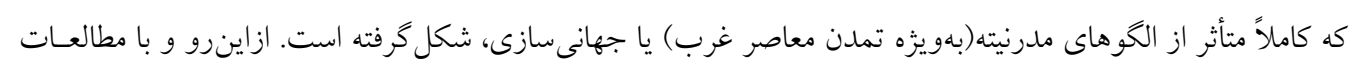

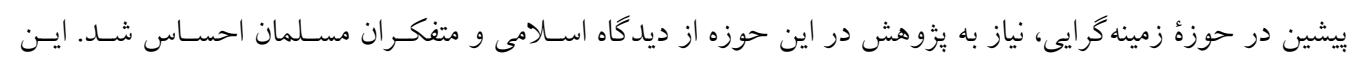

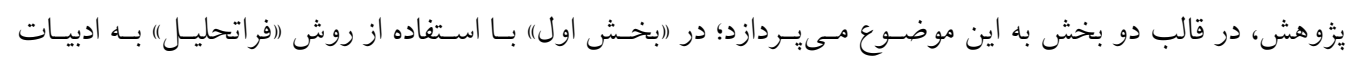

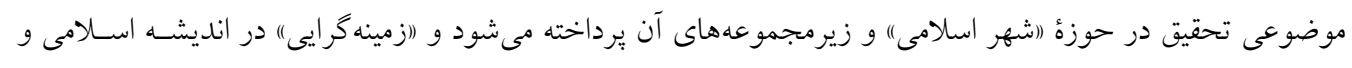

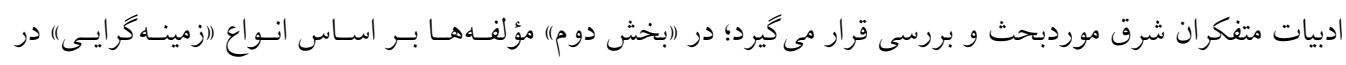

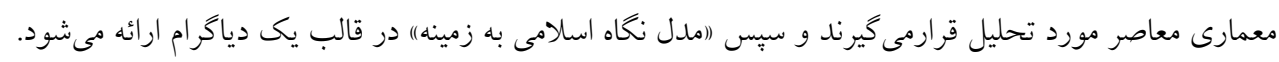

وازَّان كليدى شهر اسلامى، معمارى واكنش كرا، احترام، الكَوى زمينه كرايى، زمينه. 
بهعنوان يكى حلقهُ اصلى از رونـاند تكـاملى بــراى رســيدن بــه

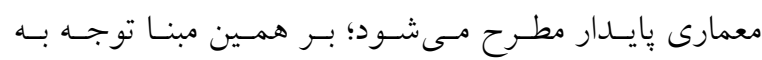
زمينههاى كالبدى، تاريخى، اقليمى - جغر افيـايى و اجتمـاعى فرهنخى زمينهُ معمارى و درك محيط بيرامون و دريافت بيـام بسـتر طــرح، از اصسـول مهــم در معمــارى يايسـدار اســت Hashempour, Nezhadebrahimi, and Yazdani 2018, ) 106). از ديخر موارد مهم در زمينه كرايى، توجـهـ بـهـ (هويـتـ) است كه (كثرت) را به (اتنوع)) نزديك مى كند و تنوع است كـه زندگى را جذاب و زيبا مىسازد (Islami 1998). در عصر جهانى شدن، معمارى نـوين متعهـد بـه در نظـر كرفتن آحاد جامعه و فرهنگهــاى كونـاكون اسـت كـه بايسـ نيازهاى روزانهُ مـردم و فنّـاورى موجـود را در نظـر كيــد و محيطى سرزنده خلق كند. جنبش روش نوين طراحى، امروزه در تلاش است مردم را در طرح، دركير كند. مانند كريستوفر الكساندر كه به دنبال طرحهايى با محوريت بيشتر مردم است. رويكردهايى كه علوم رفتارى، اجتماعى و محيطى را در نظر

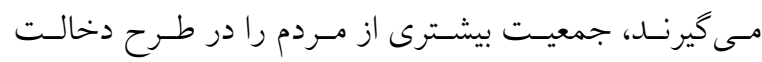
مى دهند. در ادبيات متفكران شرق نيز، بر مشـاركت مـردم در طراحسى تأكيــ شــده اسـت (Rezaei 2014, 64). اسـناد

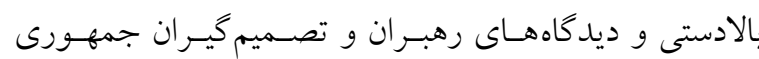
سلامى، نشان مىدهد كه آنها بهصسورت صـريح و ضـمنى،

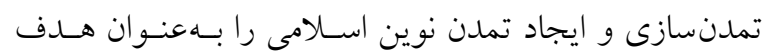
انقلاب اسلامى و نظام جمهـورى اسـلامى معرفى كـردهانـد (Ghasemi 2018, 2)؛ ازاينرو و با مطالعات بيشين در حسوزة

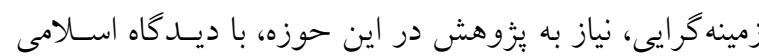

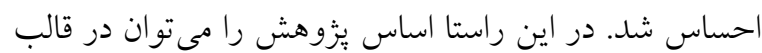
دو بخــش بيـان كــرد: (ابخــش اول)) بــا اســفاده از روش

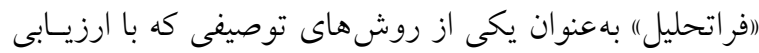
تحقيقات انجامشده، به تركيب و يكيارجهازسازى نتـايج آنهـا مى بيردازد (Seddigh 2000, 69 Quoted by Shahidi 2008) و همجنين به ادبيات موضوعى تحقيق در حوزهُ (شهر اسـلامى)"
در ادبيات معمارى جهان، معمارى اسلامى بهعنوان يك سنت

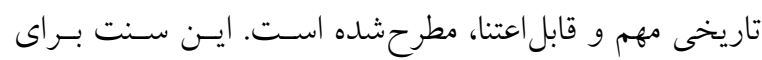

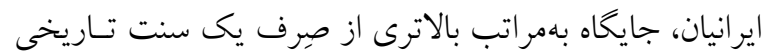

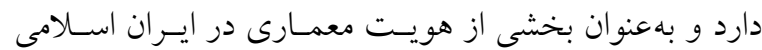
شـناخته مسى شـود (Fazelian \& Eqbali 2017, 57). ايسران معاصر، كشورى است كه داراى دو كفتمان مهم اما رقـابتى از هويت ملى اسـت: يكسى بركرفتـه از آدابورسـوم و اسـاطير

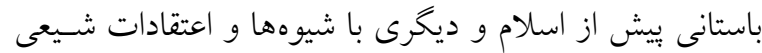
اسلامى (Mozaffari 2014). در فرهنگ ايرانى - اسـلامى، بـه دليل اتكا به نيرويسى بيـرون از اراده و قــدرت انسـان، معمـار به عنوان عابد سالك و رهخذر در اين جهـان، ظـرف زنـدكى انسان را هماهنخ با حقايق عالم و نـه بـهـمنظور خودنمـايى، طر احسى و اجــرا مسىكـرد(Taghvaie 2016). همـانطـور كـه

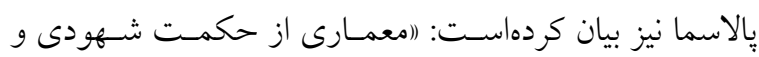

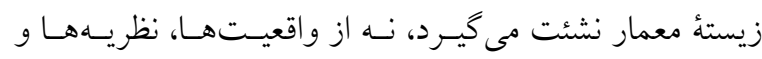

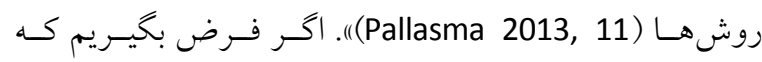
رسالت نبوى از طريق وحى براى انتقال حقايق الهى به انسـان محقق مىشود و تمــدن اسـلامى، در حقيقـت، تجلسى تحقـق جامعهُ دينى مطلوب خداوند است، هنرمند در اين جامعسه در

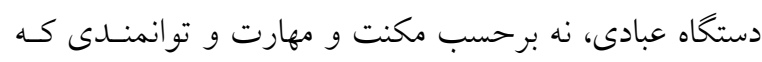

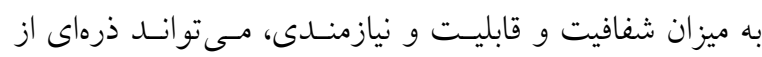

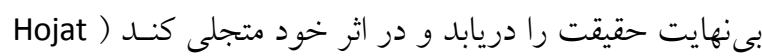
(2012, 179 وحدت در كثرت و تلاش براى رسيدن بـه يـك وحسـدت در

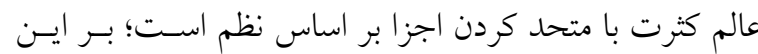
اساس، در اسلام بر عالم هستى با تأكيد بـر وجــود آفريـدگار بهعنوان منشأ يخانه و همحتِنين، بر سلسلهمراتب وجـودى، كـه خود متكى به اصل وحدت بوده و بـه امـر الهـى هماهنـع و انتظام يافته است، تأكيد مسىشـود (Nasr 1990, 54). رويكـرد

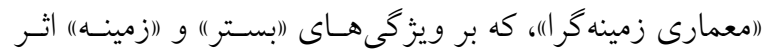

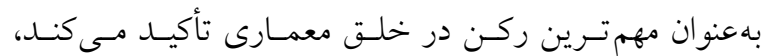


بازشناسى الكَوها و رويههاى معمارى زمينهمَرا در انديشه و شهرهاى اسلامى در عصر جهانىسازى

توصيفى - تحليلى، رويكرد (زمينه كر ايى) در معمـارى معاصـر

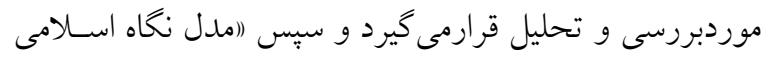

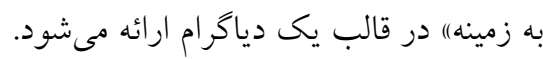

شهرسازى معاصر ايران، نتيجهُ ايـن موضـوع مهـم اسـت كـهـ

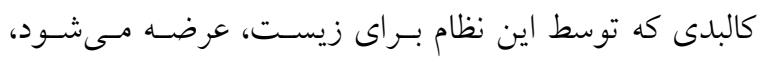

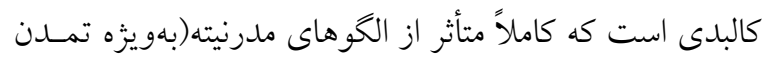

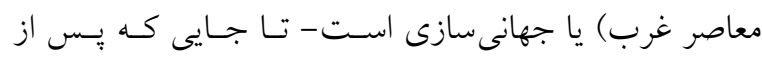
ظهور هر سبك در معمارى و شهرسازى غرب، مى تـوان آثـار

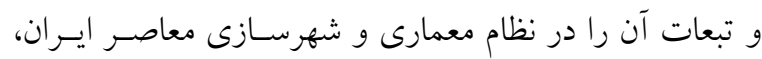

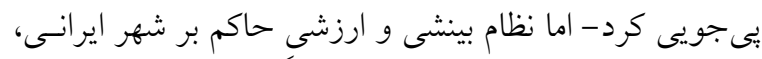

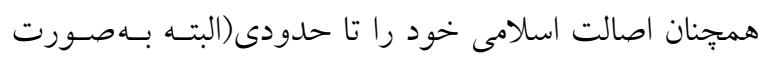

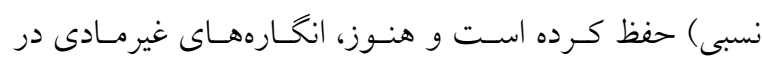

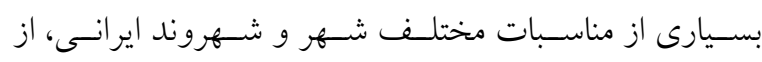

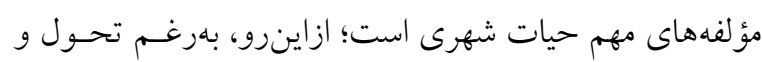

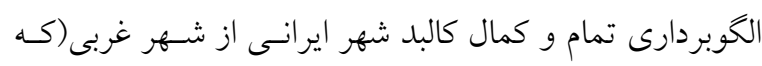

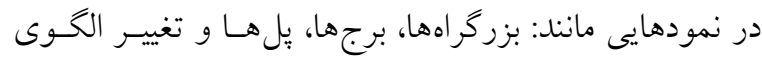

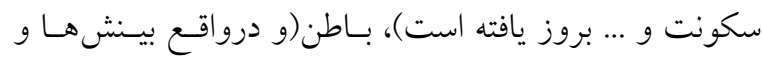

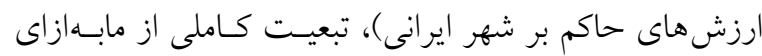

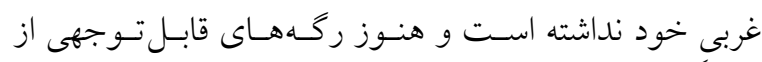

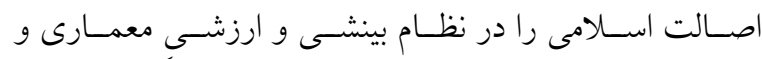

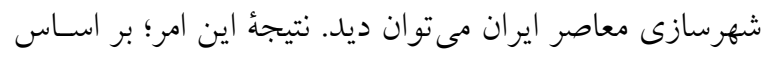

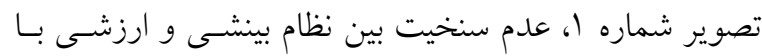
كنش ها و سبكهاى كالبدى در معمارى و شهرسازى معاصـر

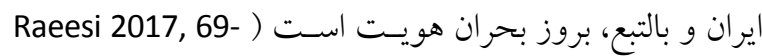

(70

\section{I-r. بيشينهُ مطالعات صورت ترفته در حوزه " دمينه}

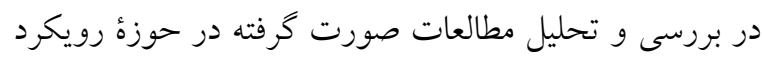

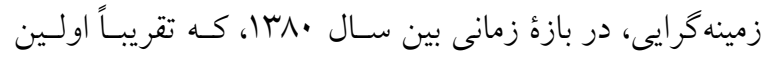
مقالة علمى به زبان فارسى در اين حوزه متتشر شــ، تـا سـال

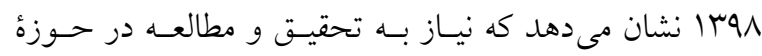
"زمينـهـرايسى در انديشـه اسـلامى" يـا در (احسوزة شـهرهاى
و زيرمجموعههاى آن يرداخته مسى شـود و (زمينـه كر ايسى) در

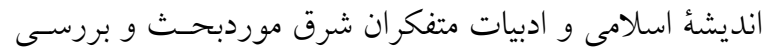

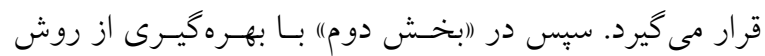

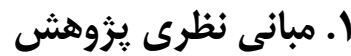

1-( ضرورتهاى استفاده از معمارى زمينه

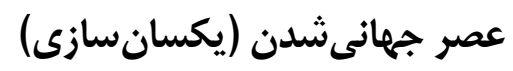

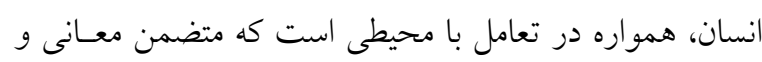

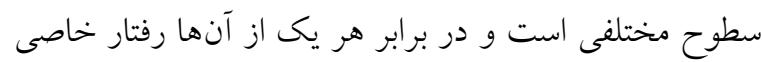

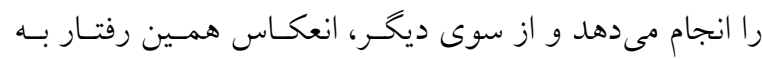

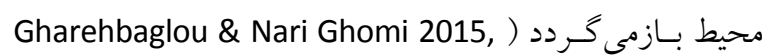

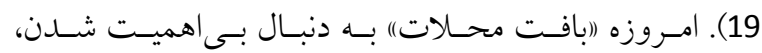

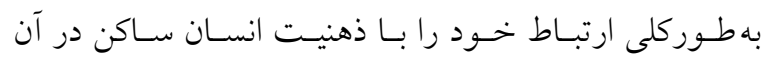
ازدستداده و او را با بحران هويت جدى مواجه ساخته است Pirbababei et al. 2016, 56) (بحر ان هويت در معمـارى و و شهرسازى معاصر ايران) موضوعى است كه تـاكنون، تأليفـات متعددى يير امون آن نخاشته شـده اسـت. در شـهر و معمـارى امروز (بيىتناسبى، بـىهـويتى، خودنمـايى، تقليسـ، فردخرايسى، مصرفزدگى، سعى در تشابه بـهـ بيخانسه، اهتمـام در تمـايز از

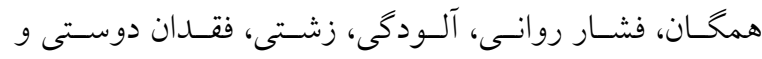

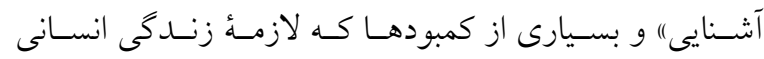
هستند، عرصه را بر انسان تنخ كرده است. تكليف نهايى هـر

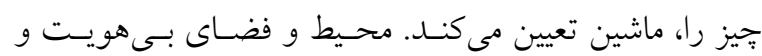

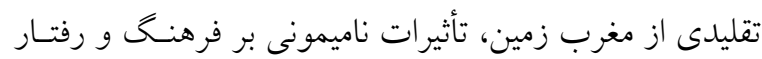

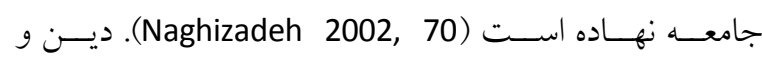
آموزههاى دينى، در كالبد شهر معاصر ايرانى، بهطوركامـل، بـهـ

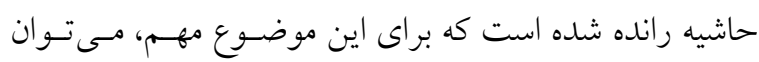

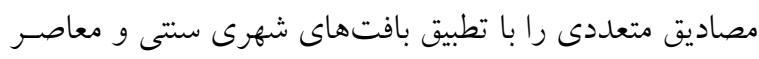

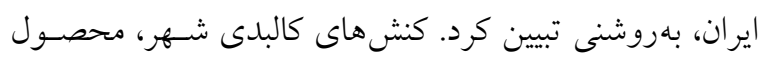

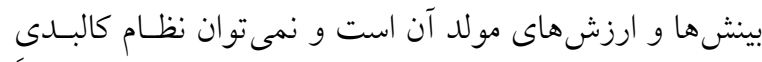

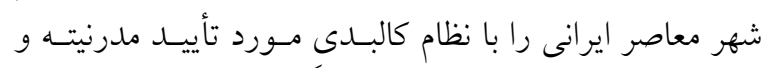

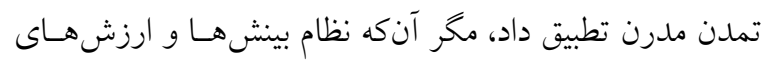

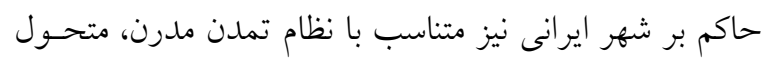

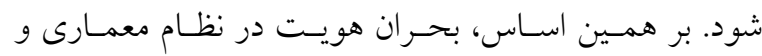




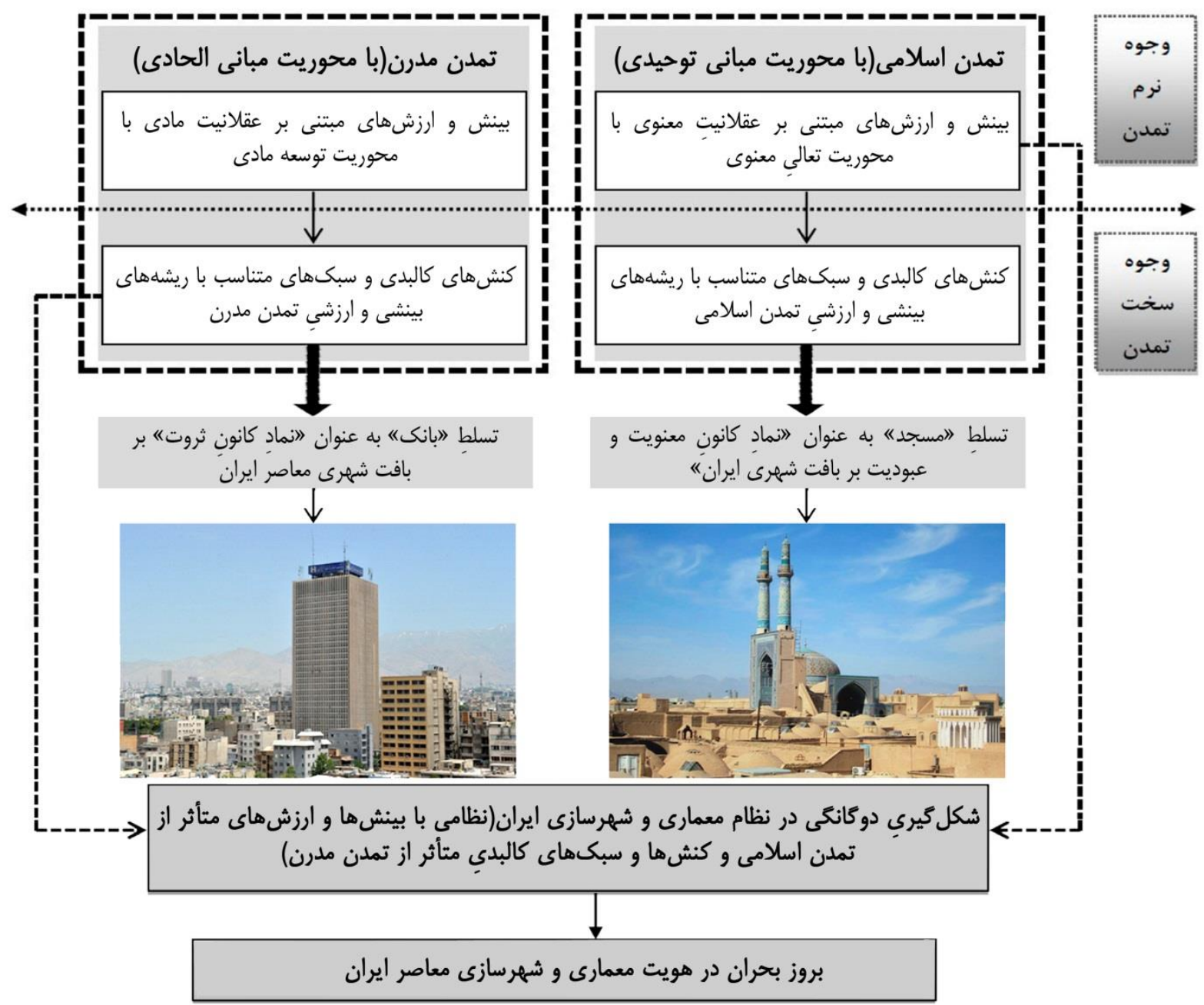

تصوير ا: بروز بحران هويت در نظام معمارى و شهرسازى معاصر ايران، به دليل عدمتجانس و تناسب مبانى بينشى و ارزشى اين نظام با كنشها و

سبكهاى كالبدى آن؛ اقتباس از (Raeesi 2017, 69, 73).

Fig. 1: The Identity Crisis in Contemporary Architecture and Urban Development of Iran due to Incompatibility and Proportion of Insights and Values of this System with its Physical Actions and Styles (Raeesi, 2017: 69, 73).

اعتبار بين المللى، تبليغ و ابزارهاى تبليغ كـه همـه وسـيله|نـد؛

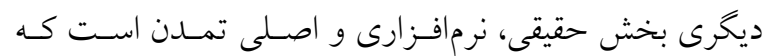

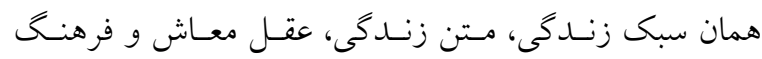
زندگى است)(Molavi 2018, 142). زمينه كرايسى در معمـارى اسلامى كه از آن با عنوان (احترام)) به بستر طرح(اعم از: زمينه

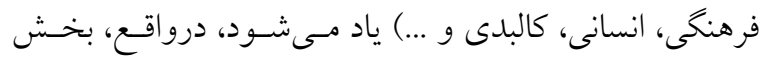
نرمافزارى تمدن اسلامى محسوب مىشود و به همـين خـاطر بررسى و تحليـل آن مطـابق جـدول شـماره ا، بسـيار حسائز اهميت است.

\section{r. شهر اسلامى}

شهر اسلامى (به معناى شهر ايدهآل از منظر اسلامى)، شهرى اسلى
سلامى" احساس مى شود. اصطلاح ("تمـدن نـوين اسـلامى)"، يكى از مهمترين و بنيادى ترين كفتمان هايى اسـت كـه رهبـر

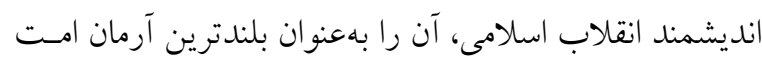

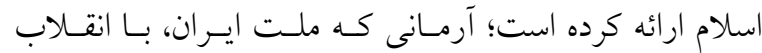

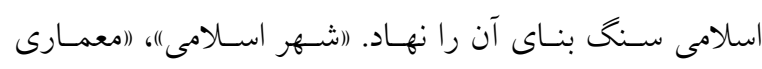

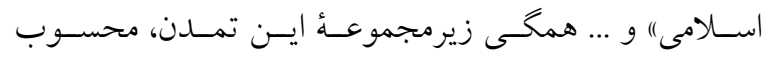

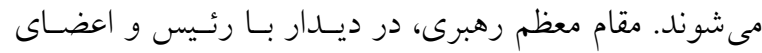
مجلس خبر گان رهبرى، در شهريور سال بوسا، ضسمن بيـان

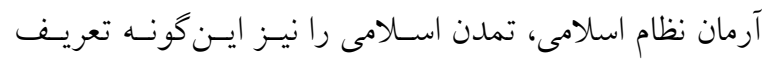
مى كنند:(اتمدن نوين اسلامى دو بخش دارد: يكى بخش ابزارى

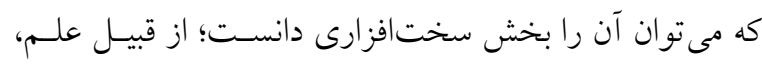

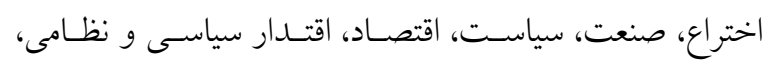


بازشناسى الكَوها و رويههاى معمارى زمينهمَا در انديشه و شهرهاى اسلامى در عصر جهانىسازى

جدول ا: بررسى "مطالعات صورت كرفته در حوزه "زمينهكر ايى" در ايران Table 1: Review of 'studies in the field of "contextualism" in Iran

\begin{tabular}{|c|c|c|c|}
\hline موارد مطرحشده & نويسنده & نام يزوهش و تاريخ آن & رديف \\
\hline 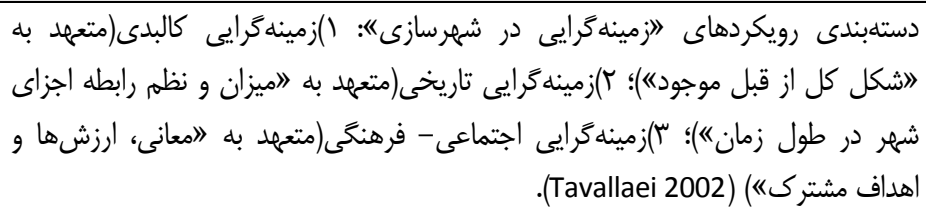 & نوين تولايى & زمينهكَرايى در شهرسازى، & 1 \\
\hline 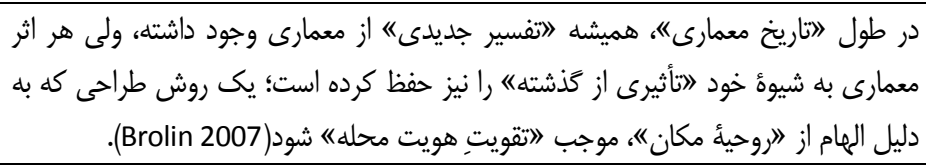 & 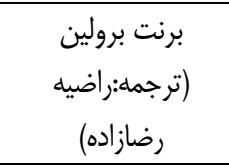 & 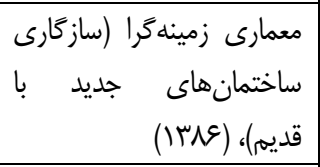 & $r$ \\
\hline 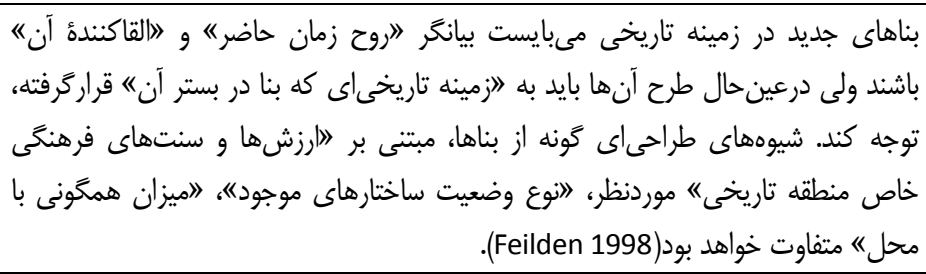 & 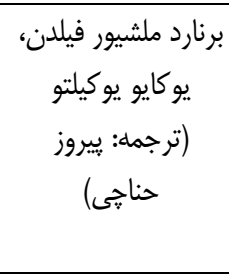 & 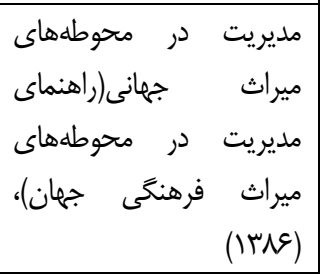 & r \\
\hline 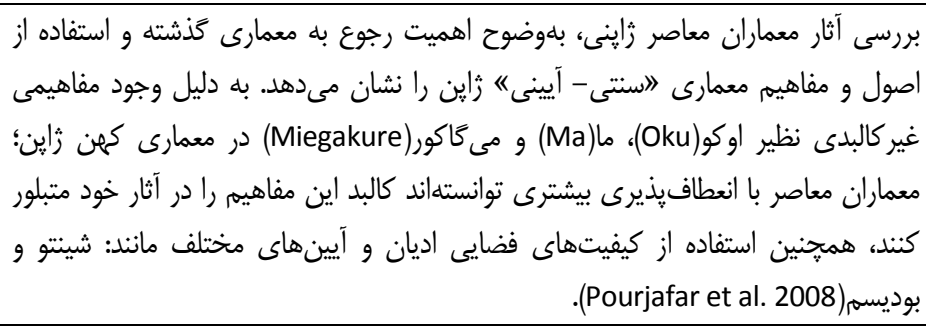 & احسان رنجرا يورجعفر، آرين & 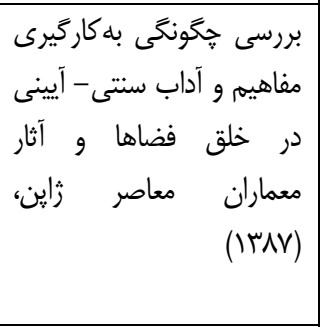 & r \\
\hline 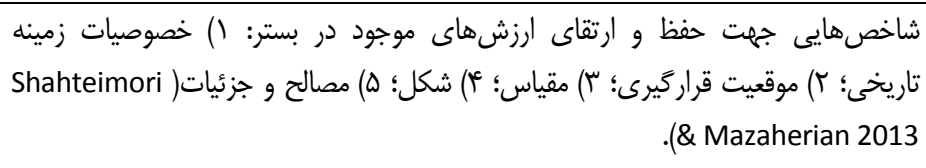 & يلدا شامد مظاهريمورى، & 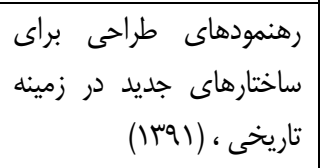 & Q \\
\hline 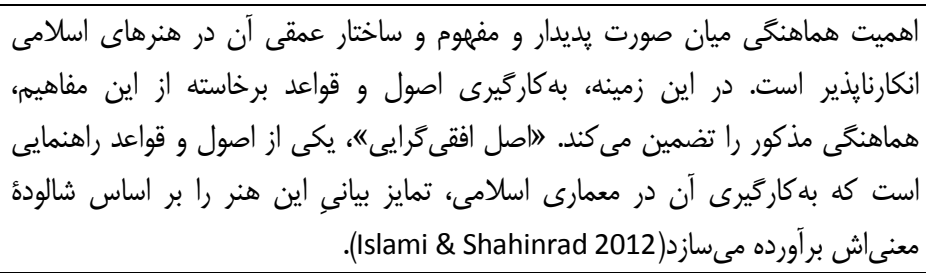 & ساسلامى، مهنوش & 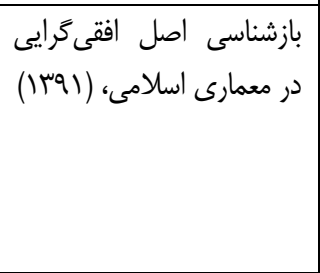 & 9 \\
\hline 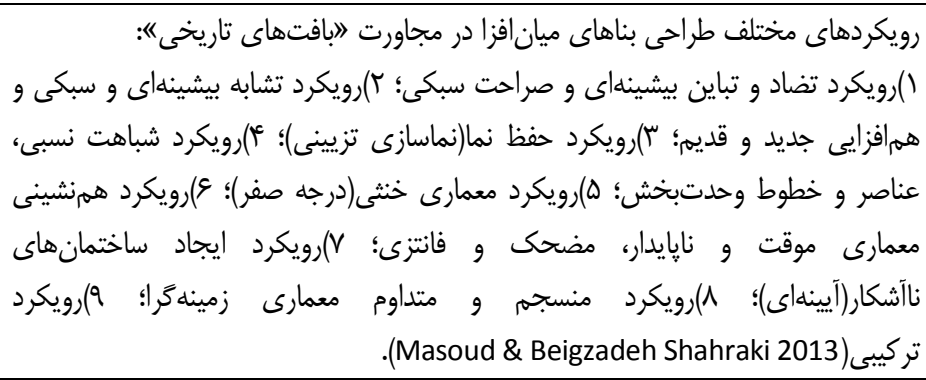 & محمد مسعود، & 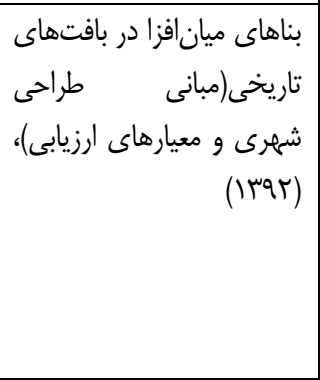 & 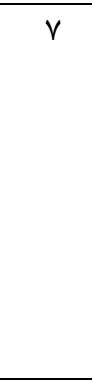 \\
\hline 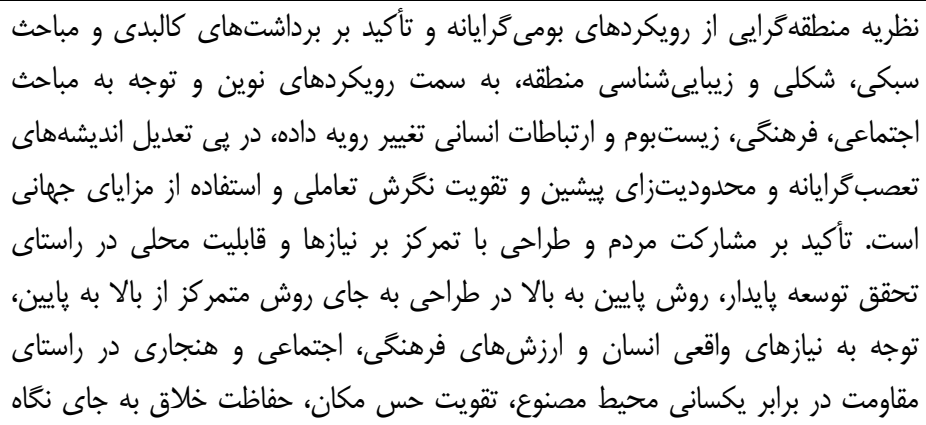 & 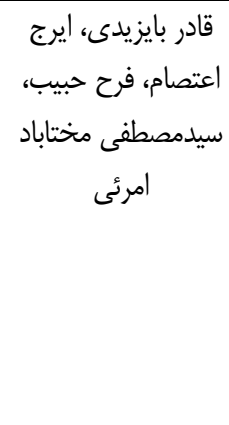 & 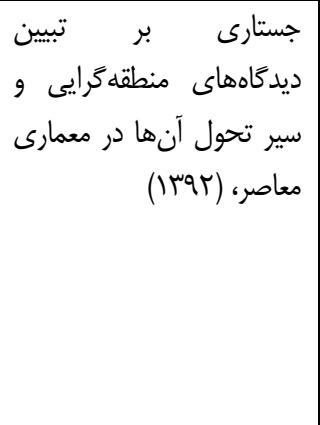 & $\wedge$ \\
\hline
\end{tabular}




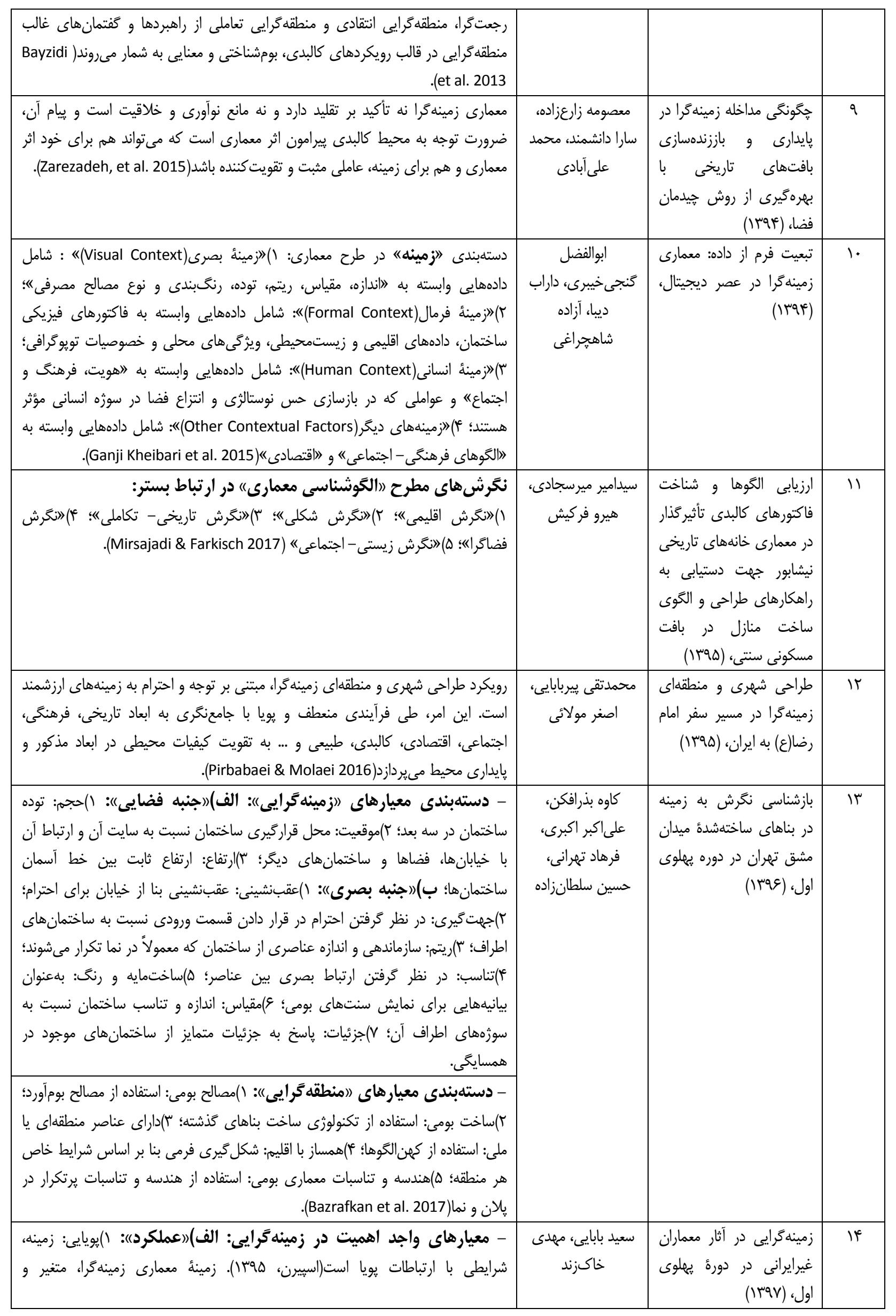


بازشناسى الكَوها و رويههاى معمارى زمينهمَا در انديشه و شهرهاى اسلامى در عصر جهانىسازى

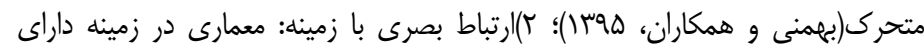

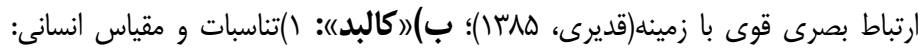

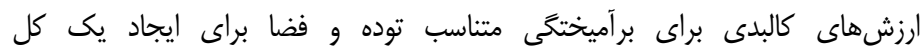

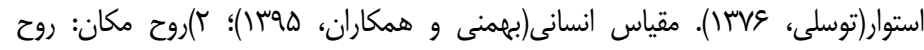

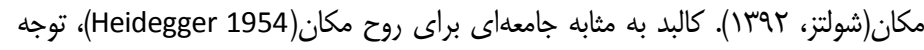

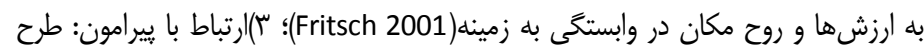

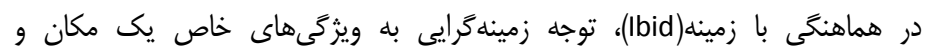

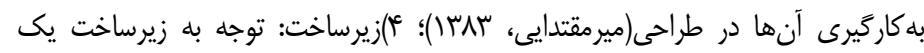

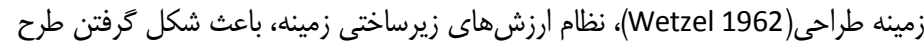

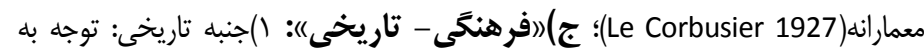

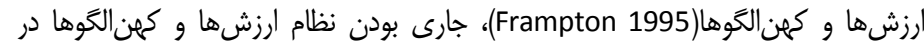

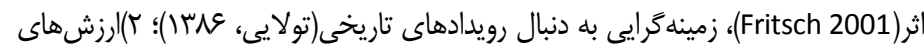

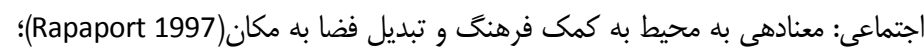

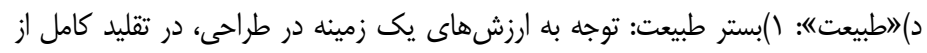

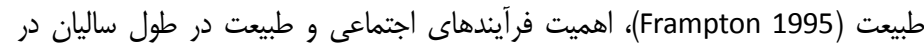

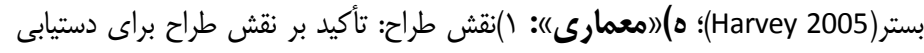

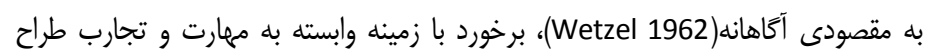

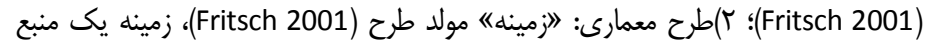

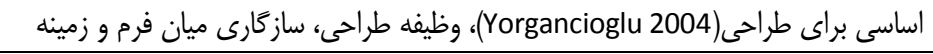

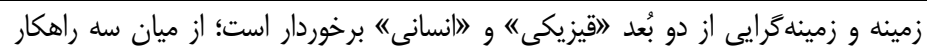

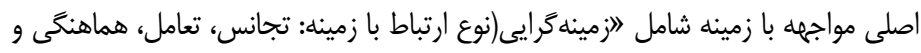

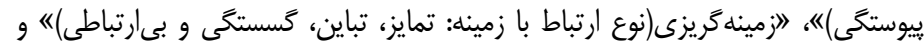

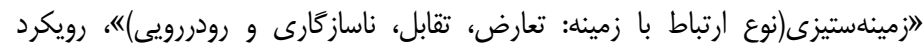

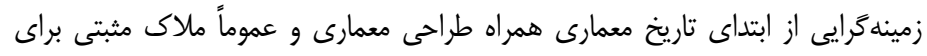

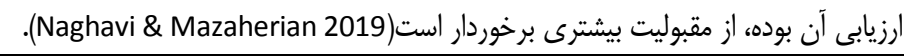

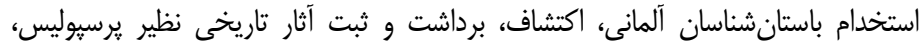

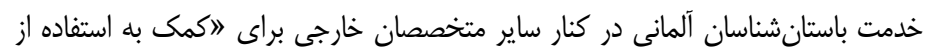
مضامين باستانى" در "امعمارى" (Mirzahosseini et al. 2019).

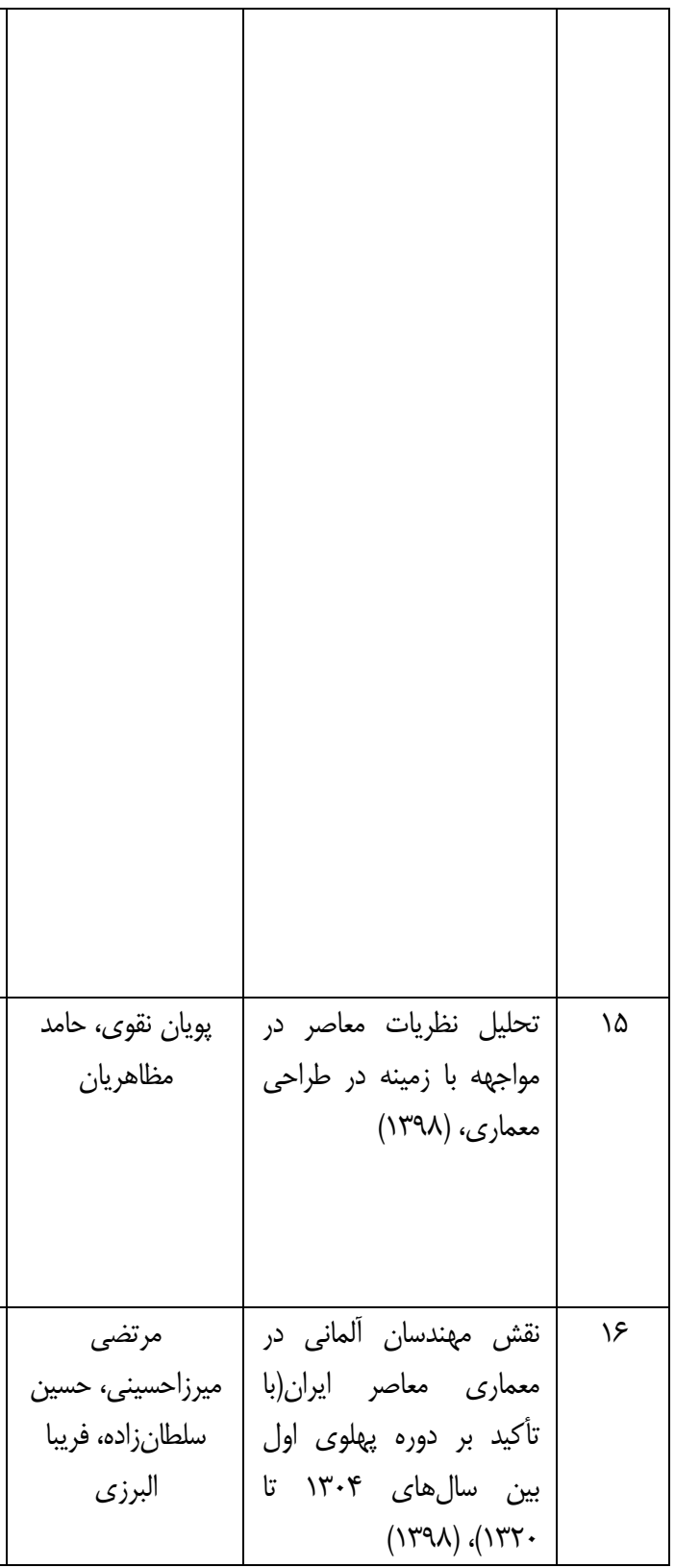

را در جهت جغرافيايى قبله قرار دهند، بلكه منظـور آن اسـت

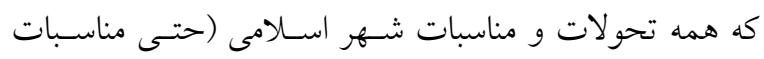
غيرعبادى نظير سكونت) بايد بر حقيقتِ محور قبله كه همانسا

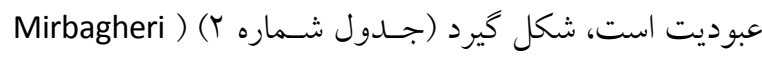
.(2014, Quoted by Raeesi 2017, 63- 69

r-1 بايدهاونبايدهاى (اشهر اسلامى)" از نظر كالبدى و عملكردى در قرآن و احاديث

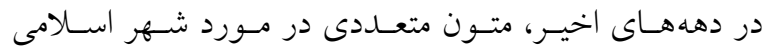

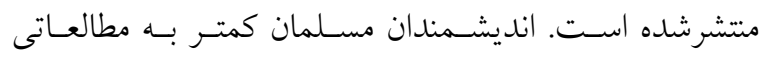

مسجدمحور است و ركن كالبدى و ماهوى آن، مبتنى بــر ايسن

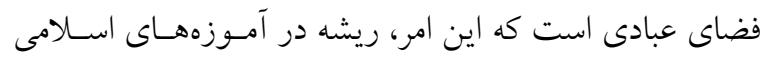

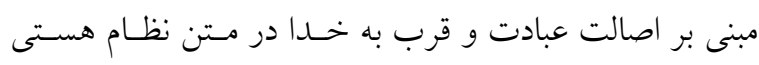

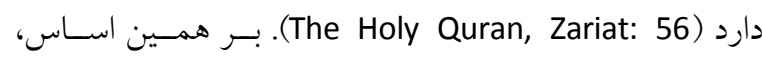

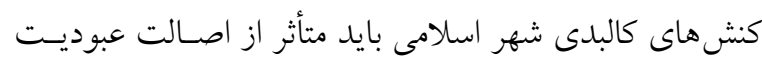

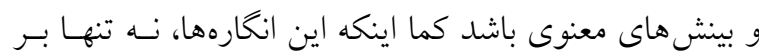

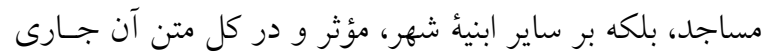

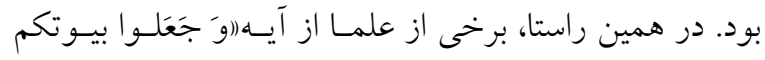
قبله) (The Holy Quran, Yunes: 87) جنين استنباط كردهانـد كه منظور اين آيه، اين نيست كه همه شهروندان مسكن خهود 
جدول r : تحليل "شهر اسلامى"

Table 2: Analysis of "Islamic City"

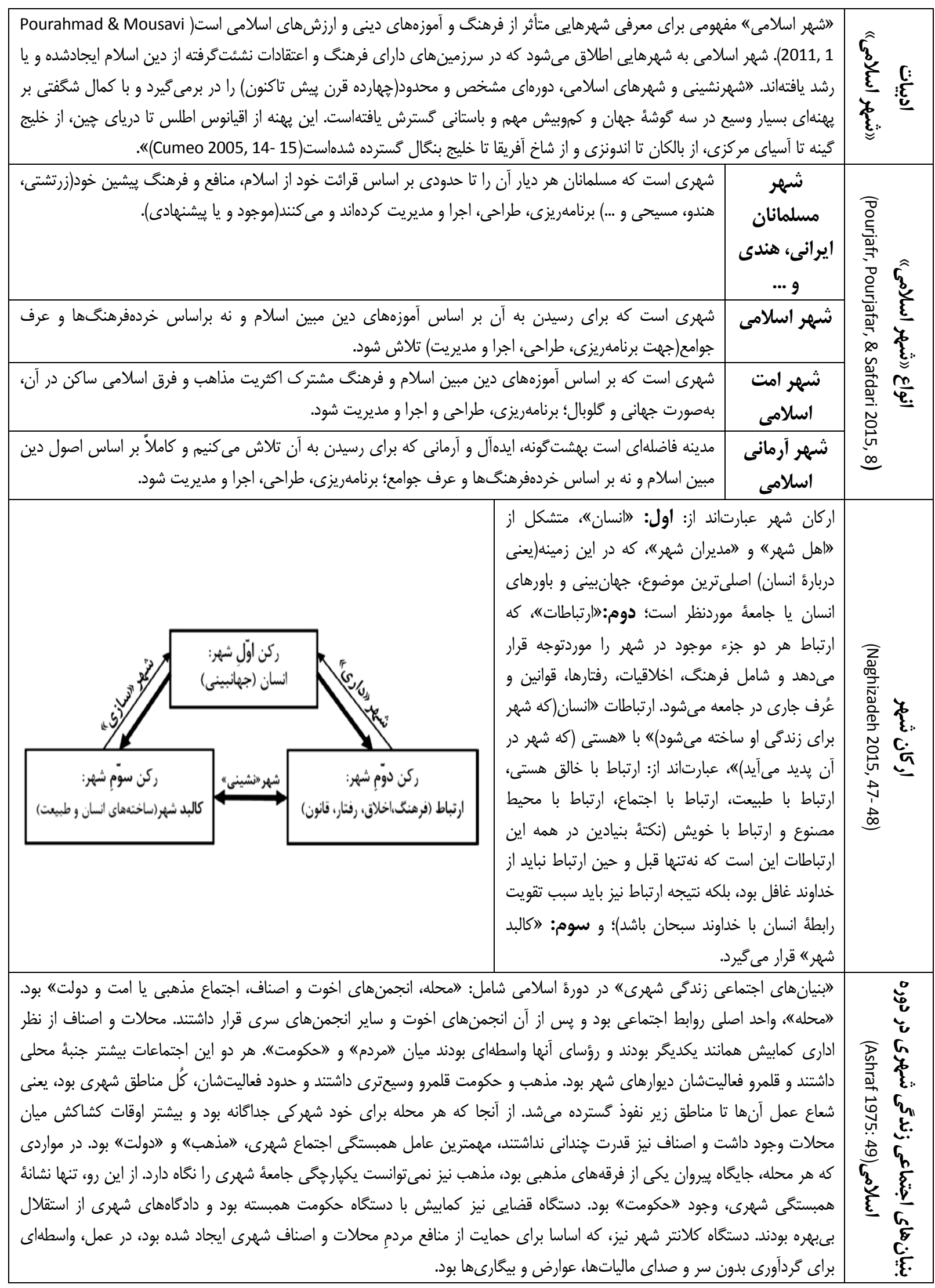




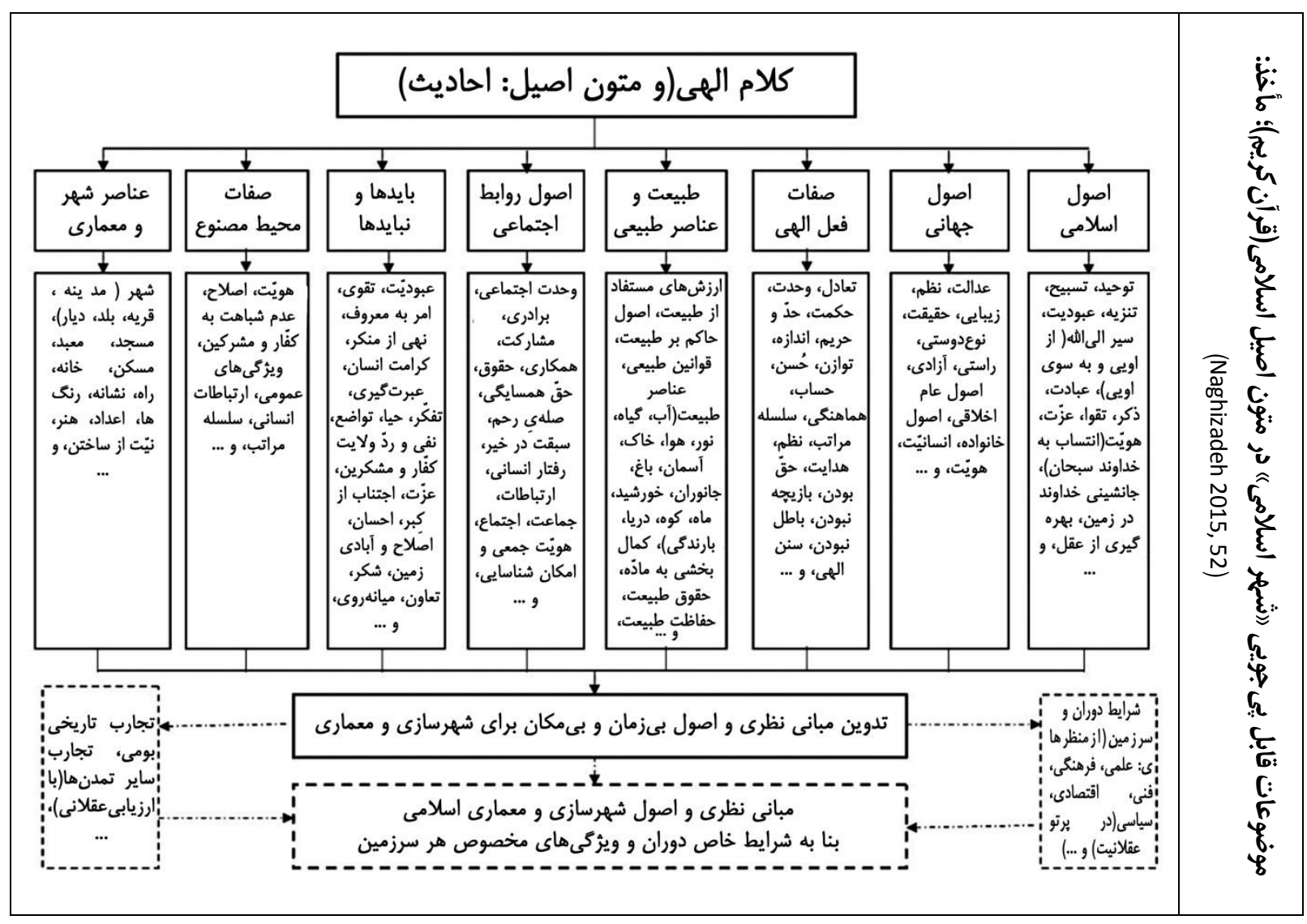

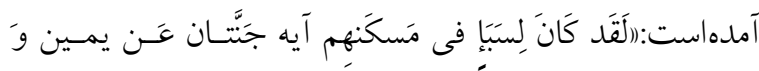

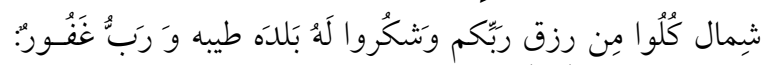

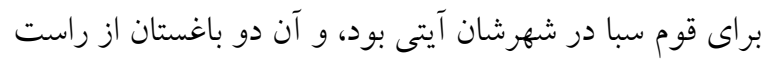

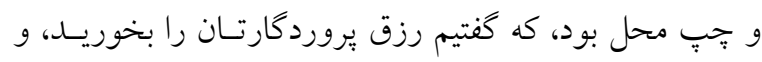

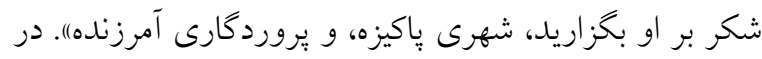

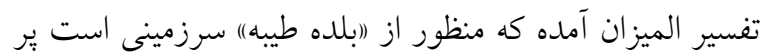

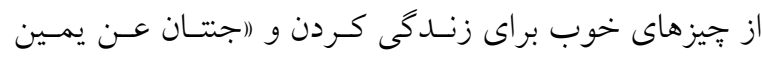

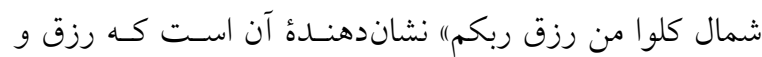

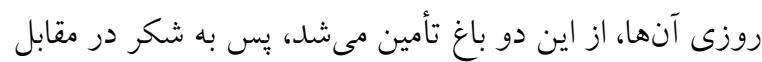

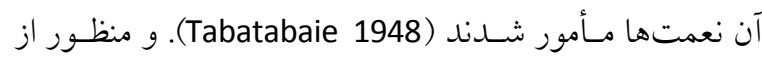

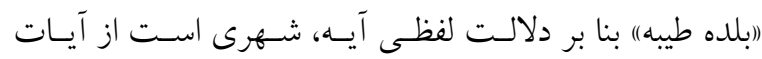
خداوند كه از طرفين (جِ و وراسـت) در ميـان بـاغهـا قـرار

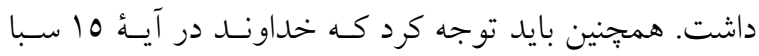
فرموده است: (اشكروا له بلده طيبه و رب غفور)) كه بـا توجـهـ به معناى آيه، نتيجه مى شود كه براى شهرى كه صفت ("طيبـه)

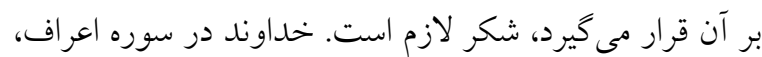

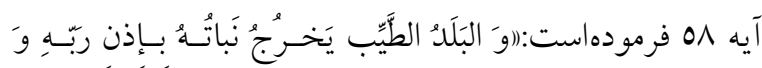

ميرامون تعريفى شفاف از شهر اسلامى، شاخص سازى، نحسوه

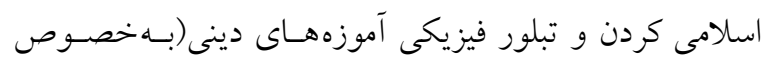

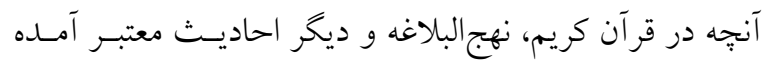

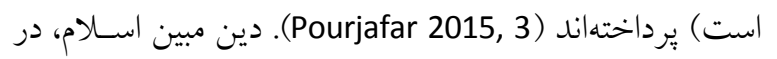
عرصه هاى مختلف زندكى انسـان اصـول و معيارهـايى دارد؛ بلاشك اين معيارها شامل برنامهريزى و طراحسى شهـرى نيـز مىشود. مبانى تئوريك شهرسازى اسلامى مى تواند مبتنى بـر

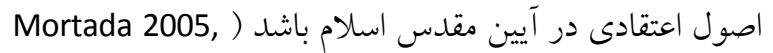
8 -7). با تكيهبر آيات قرآنكريم، اوصاف و ملاكهـايى بـراى تعريف و ساختن شهر به معناى قريه مطلوب اسـلامى وجـود دارد. برخى از اين اوصاف شاخص را در آياتى همدِون (آيـهـ

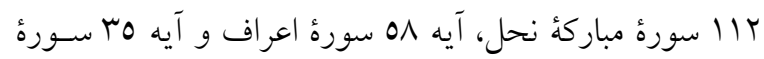

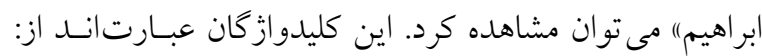

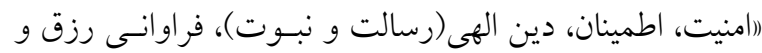

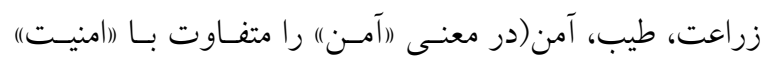

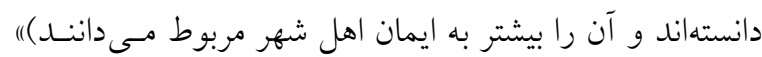

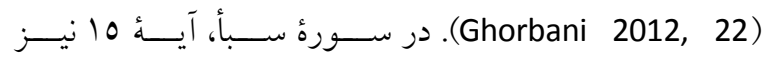


سياس مسى كزارنــ (The Holy Quran, Eraf:

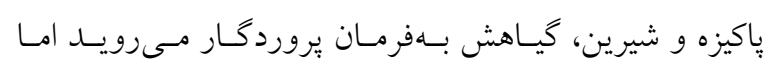

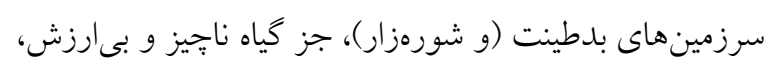

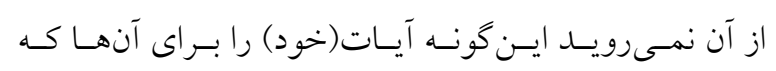

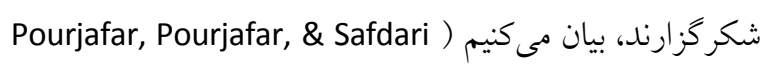

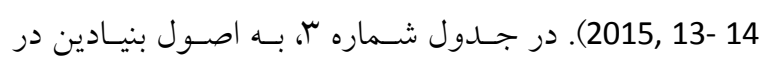

شكل گيرى و تكامل شهر ايرانى -اسلامى برداخته شده است.

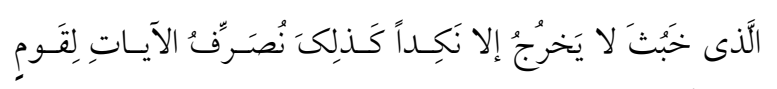

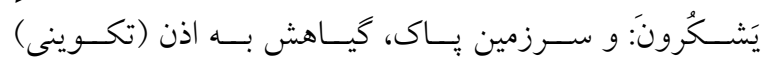

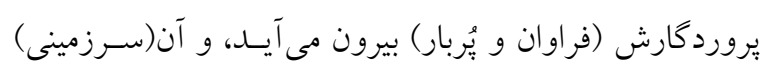
كه بليد است(كَاهش) جز اندى و بـى خبر بيرون نمى آيــا (از

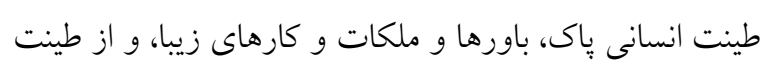

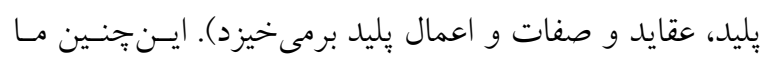

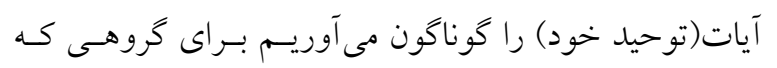

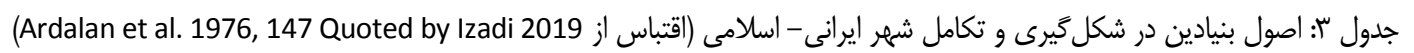
Table 3: Basic principles in the formation and evolution of Iranian-Islamic city (Ardalan et al. 1976, 147 Quoted by Izadi 2019)

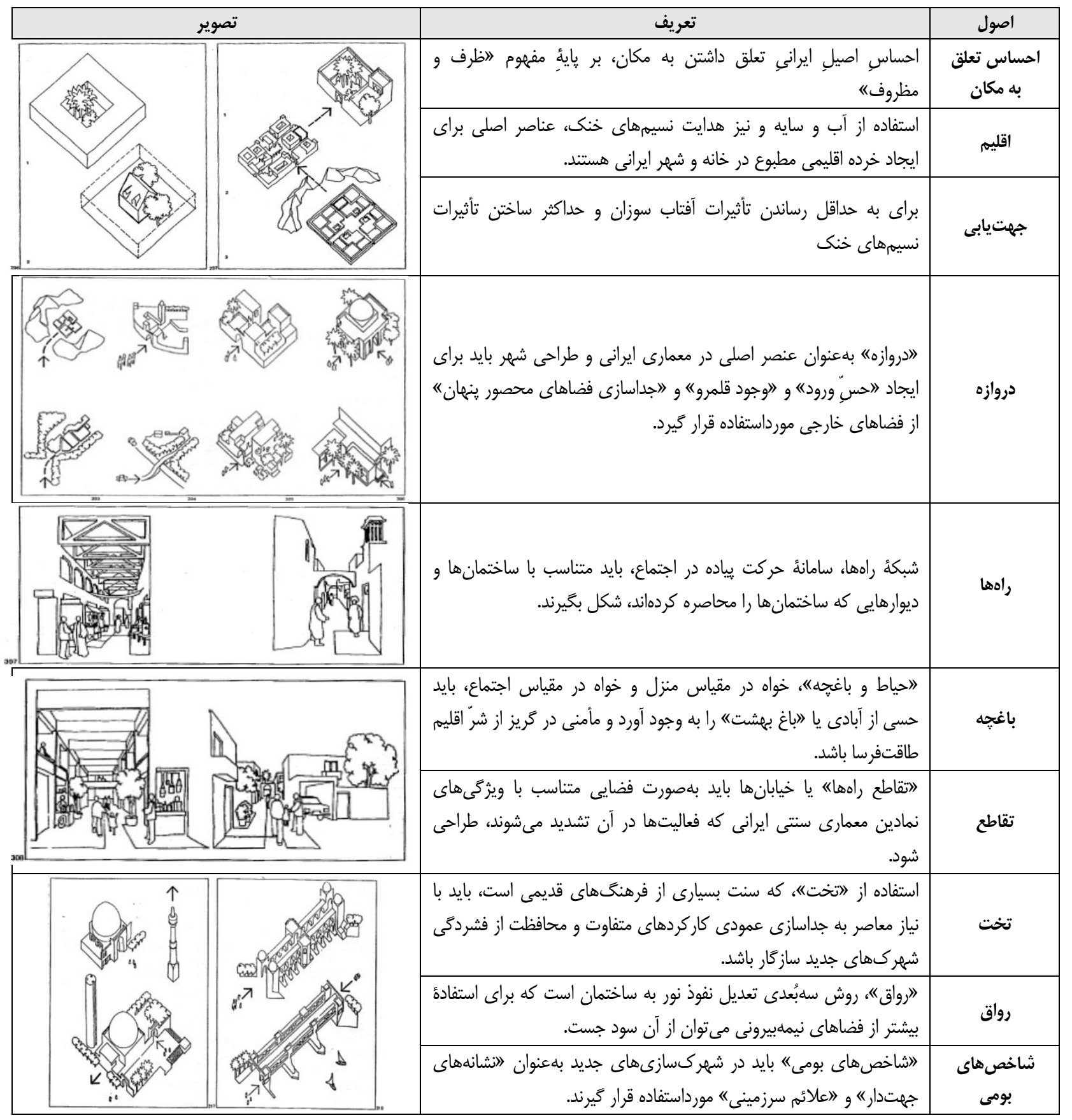


بازشناسى الخوها و رويههاى معمارى زمينهكَا در انديشه و شهرهاى اسلامى در عصر جهانىسازى

جدول ثا: برخى نمودها و ساحتهاى اخلاقى (احترام يا زمينهَّرايى) در معمارى اسلامى (Nezhad Ebrahim \& Farshchian, 2014, 120) Table 4: Some appearances and ethical aspects(respect or contextualism) in Islamic architecture (Nezhad Ebrahim \& Farshchian, 2014, 120)

\begin{tabular}{|c|c|c|}
\hline اثر اخلاقى منتج شده & اثر كذاشته شده بر محيط و افراد & مؤلفه معمارى \\
\hline محترم داشتن ديكران بر خود & ارزش نهادن بر افراد مهمان و افراد ساكن مكان معمارى با توجه به سنت و مذهب & سلسلهمراتب حضور \\
\hline آرامش روانى و فكرى & آسودمخاطر بودن افراد در مكان معمارى ازلحاظ ارزشى و مذهبى & محرميت \\
\hline 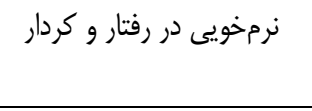 & زيبايى محيط زندگى براى تأثير بر نرمخويى و آرامش روانى افراد ساكن در مكان & ت تزئينات \\
\hline آرامش اعصاب و رفتار & ايجاد محيطى آرام و به دور از هياهوى بيرون براى آرامش خاطر ساكنان & 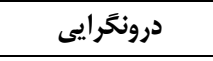 \\
\hline تقويت فروتنى معنويت & احترام به مقام انسان و فاخر نمايش ندادن ماديات در مقابل معنويات & تناسبات \\
\hline
\end{tabular}

(اسلام) به عنوان يك دين كـاملاً اجتمـاعى، تمـام توجـه خود را بهمراتب زندگى و تحقق امت واحسلدة اسـلامى منستج

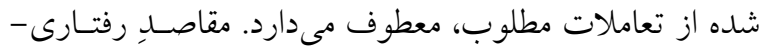

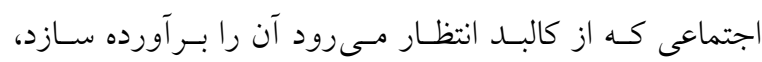

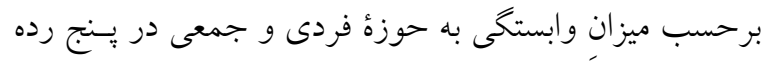
طبقهبندى مىشود: (اخلوت، قلمرويايى، ابراز هويـت، ارتبـاط

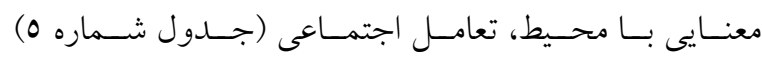
.((Gharehbaglou, Farshchian, \& Alian 2016, 1)

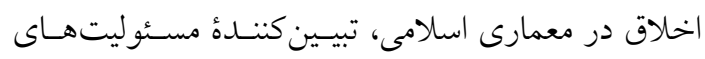

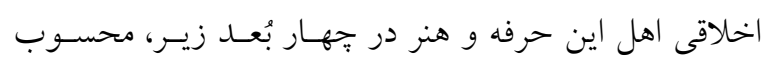

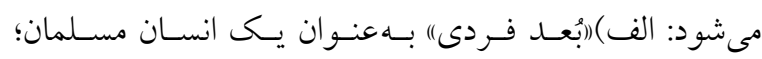

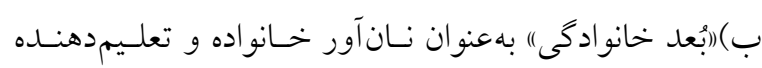

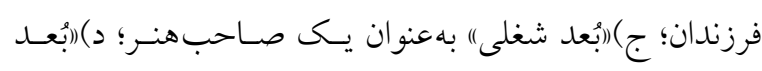

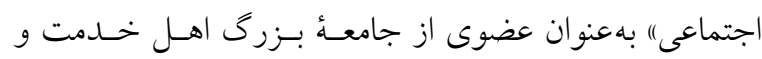

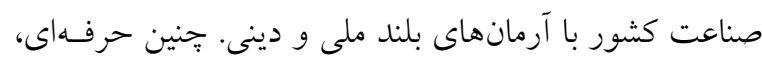

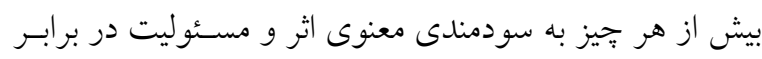

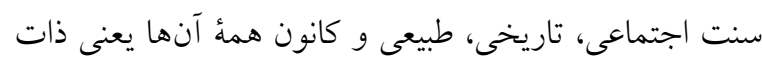

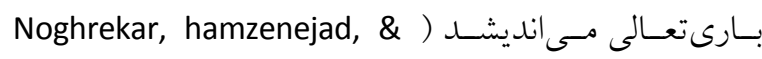
(Forouzande 2009, 41

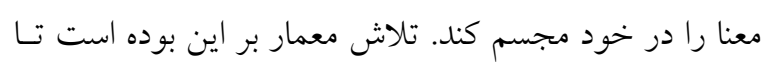

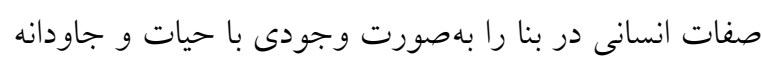

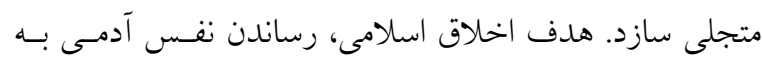

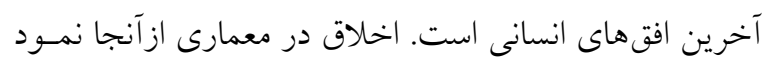

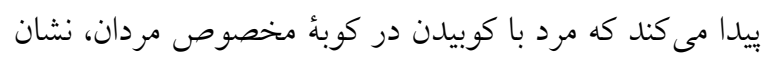

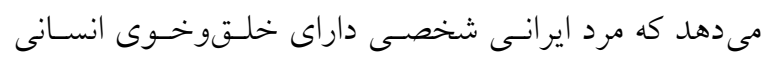
است. وارد هشتى مىشود؛ بعد ميانسر ا و ديخر فضاها، تمام

\section{r-r. زمينههاى ("شهر اسلامى)"}

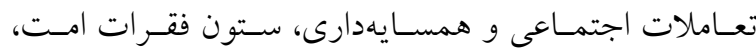

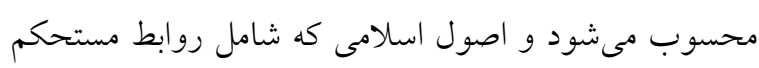

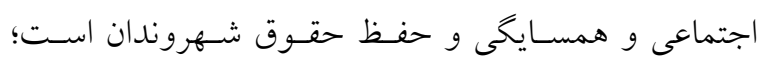
مى تو اند موجب ارتقاء وضعيت اجتمـاعى در شهرهـا شـوده.

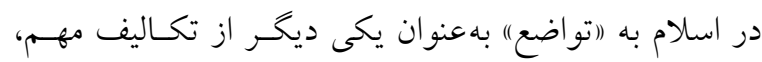

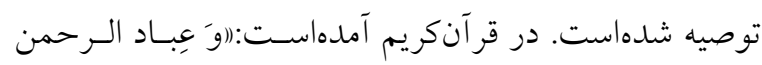

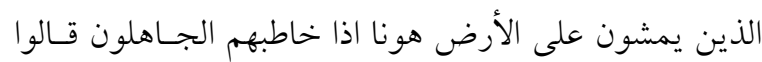

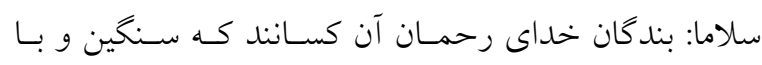

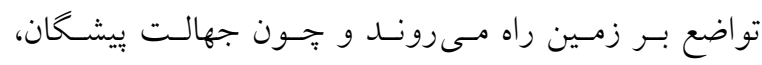

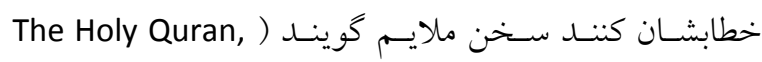

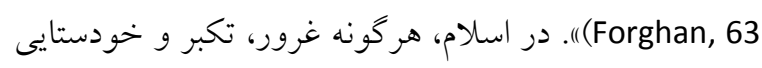

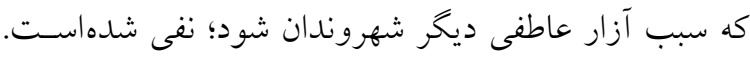

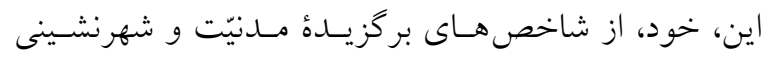

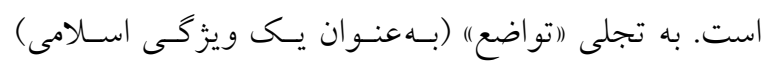

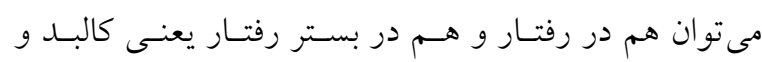

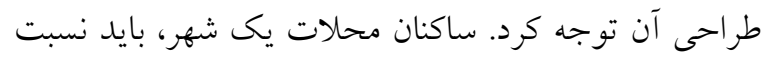

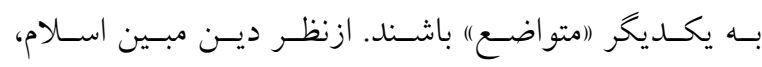

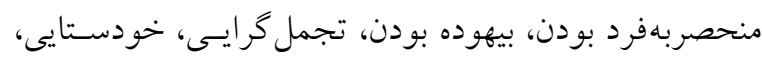

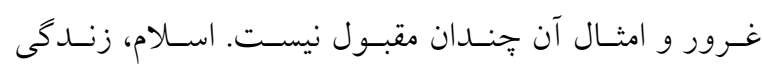
تجملاتى را سبب ضعف، ناتوانى و انحطاط جامعه و نشـانه

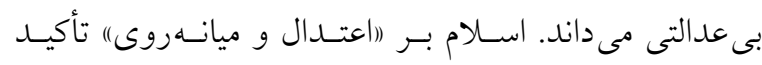

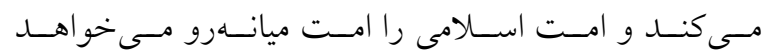
(Pourjafar, Pourjafar, \& Safdari 2015, 4- 5)

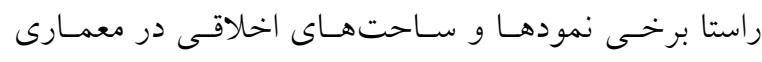

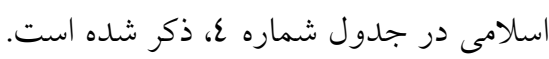


جدول ه : تأثير هنجارهاى اجتماعى اسلامى در يذيرا يا غيريذيرا بودن افراد براى تحقق تعاملات اجتماعى (1) Gharehbaglou, Farshchian, \& Alian 2016 (1

Table 5: The impact of Islamic social norms on whether or not individuals are receptive to social interactions(Gharehbaglou, Farshchian, \& Alian 2016, 1)

\begin{tabular}{|c|c|c|c|c|}
\hline \multicolumn{5}{|c|}{ جامعه اسلامى } \\
\hline ثمره در تعاملات اجتماعى & نتيجه توجه به هنجار از طرف & خصيصه اكتساب شده & بيامد حاصل از رعايت هنجار & هنجار اجتماعى \\
\hline \multirow{6}{*}{ 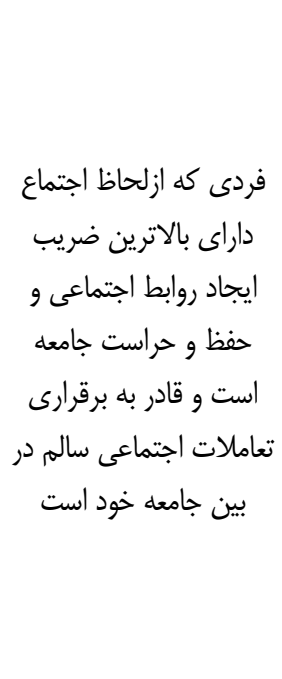 } & \multirow{6}{*}{ 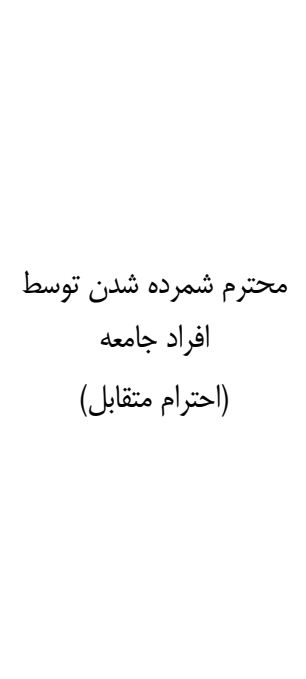 } & خلق نيكو & انجام فرائض دينى - الهى در خصوص نوع رفتار & اخلاق \\
\hline & & نفس فروتن & صرفنظر از خواستههاى شخصى و تلاش در & حفظ عزت \\
\hline & & هويتمند & اهميت دادن به آدابورسوم "فرهنكى - سرزمينى" & ستتهام به \\
\hline & & عطوفت طبع & 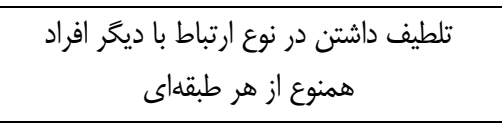 & حسن معاشرت \\
\hline & & رعايت كنندة حقوق & تقيد به ارزشها وهنجارهاى اجتماعى جامعأ & تعصب ورزيدن \\
\hline & & قابل اعتماد بودن & $\begin{array}{c}\text { احساس وظيفه و مسئوليت داشتن نسبت به ديخران و هويت سرزمينى } \\
\text { وانى }\end{array}$ & مسئول بودن \\
\hline
\end{tabular}

ما زنده مى كنـد و شـناخت مـا از مكـان را ممكـن مسىسـازد (جدول شماره ( )

r

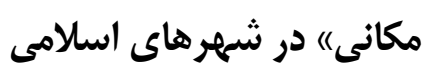

بديدهاى كه امروز با آن مواجه هستيم را شايد بتوان الهان (امقاومت

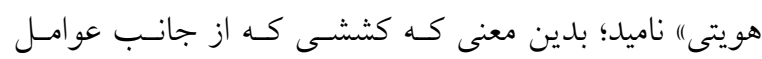
خارجى از قبيل حركت به سمت مــدرن شـدن(يا بـه عبـارت

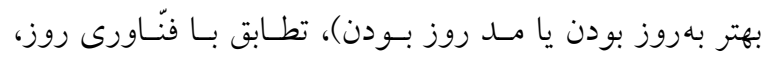

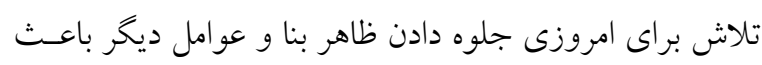

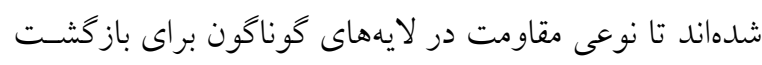
و نخاهى دوباره به بيشينه موجود، به وجود آيــ ( Hooshyar

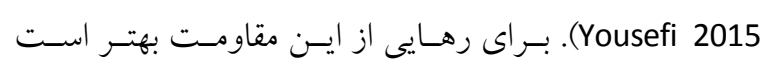

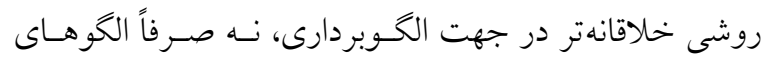
فرمى، بيدا كرد، راهبردهايى كه هر يـك مسىتو انـــ بـهـعنـوان فرآيندى در جهت (الخوبردارى هوشمندانه از (هويت مكانى)" در بافت تاريخى شهرهاى اسلامى") مورداسـتفاده قـرار گيــرد

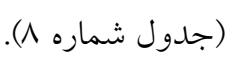

اين مراحل سير اخلاقيات است و بس. هـدف آن دور كـردن يليدىها و ارزش كذارى بر خوبىهـا اسـت Nejad Ebrahim) (and Farshchian 2014, 120)

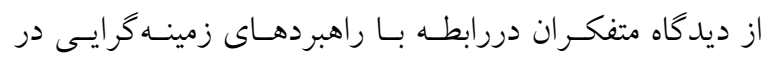
انديشهُ اسلامى مى بيردازد.

\section{ץ-"r. عوامل شكلدهنده به (هويت مكانى) در سازمان شهر اسلامى سول}

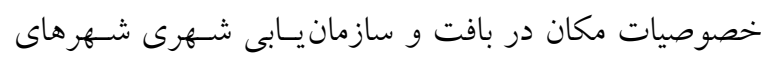
اسلامى كه ما را بهسوى درك هويت مكان رهنمون مىسـازد، بهصورت (اسيما و جششمانداز، نظم فضـايى، رويــاد، خـاطره، Taban et al. ) جهت كيرى و يخانه بندارى") قابل تفكيك است

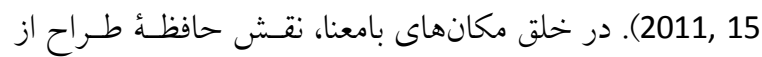
محيطهاى واجد معنـا را نيـز بايـــ در نظـر كرفـت. بسـيارى تجربئ مكان را نشئت كرفتـه از نحـوهُ ارتبـاط بـين شـخص و

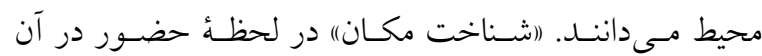
صورت مى گيرد كه ساختار كالبدى با خصوصياتش، تجـارب ما از مكان، خاطرهها و احساسهاى وابسته به مكـان را بـراى 
بازشناسى الكَوها و رويههاى معمارى زمينهمَا در انديشه و شهرهاى اسلامى در عصر جهانىسازى

جدول 9 : راهبردهاى زمينه

Table 6: Contextualism strategies in Islamic thought from the perspective of thinkers

\begin{tabular}{|c|c|c|}
\hline موارد مطرحشده & انغاره(ديدكاه) & متف \\
\hline 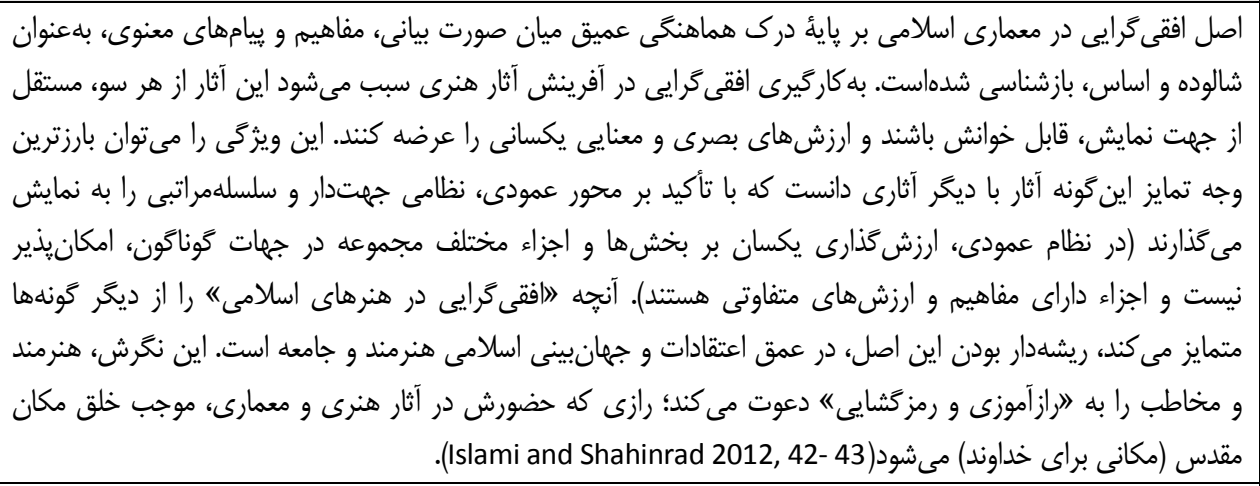 & اصل افقى درايى & 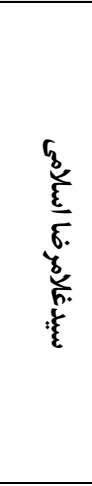 \\
\hline 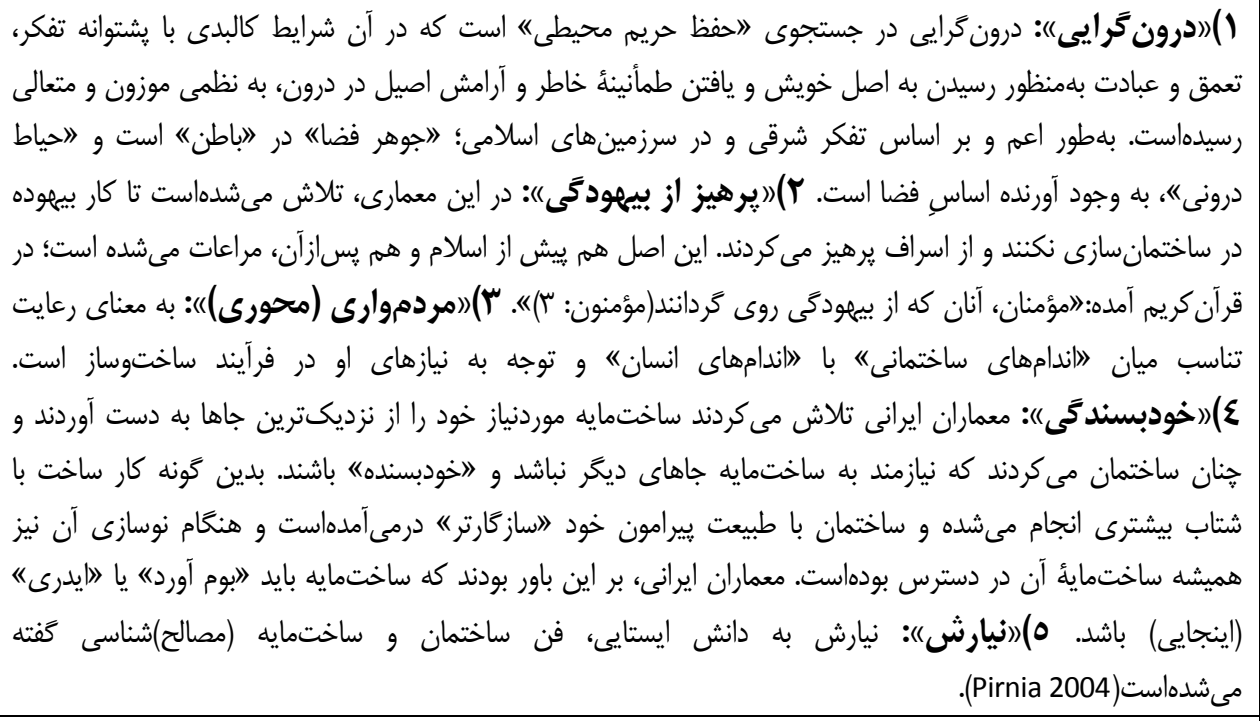 & 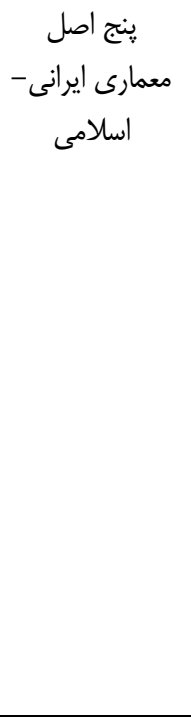 & 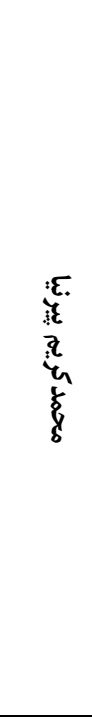 \\
\hline 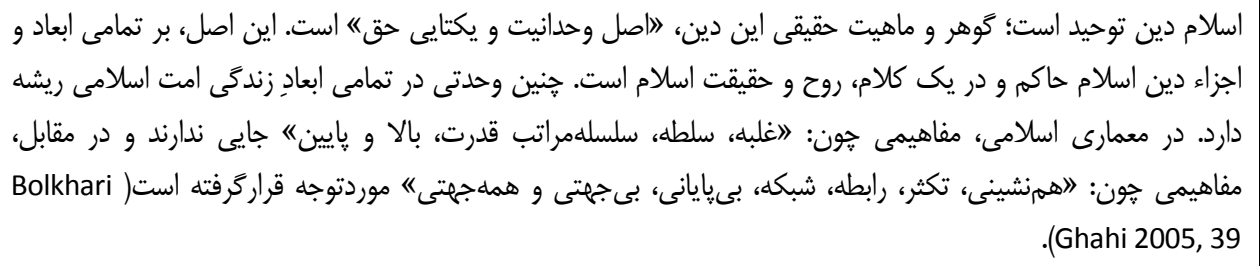 & 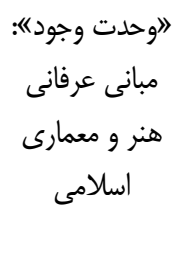 & 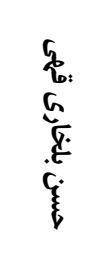 \\
\hline 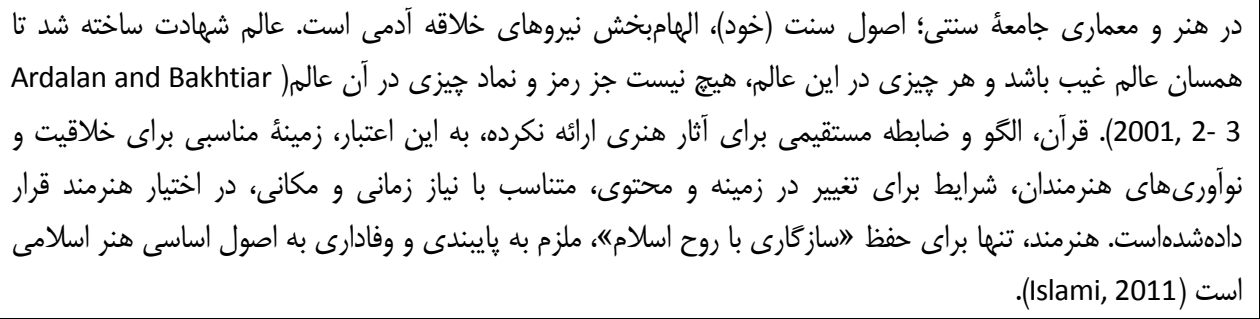 & سنت عرفانى در & 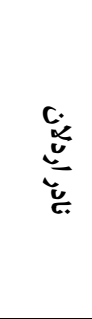 \\
\hline 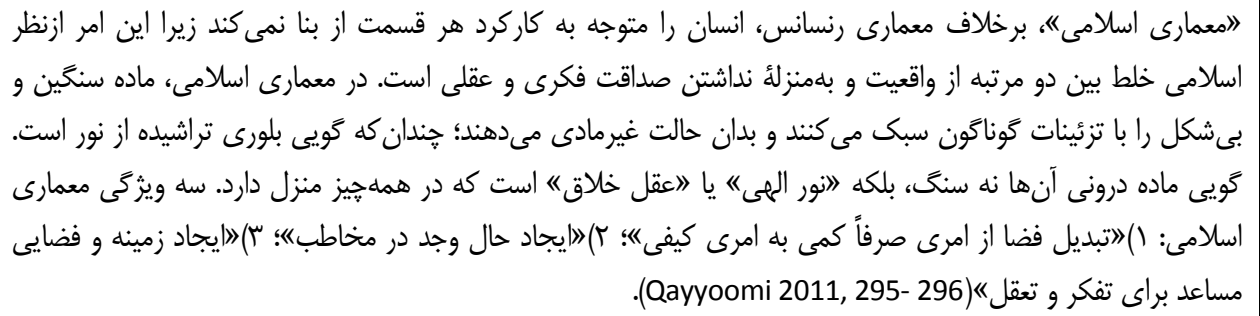 & معبانى و تاريخ & 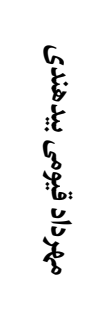 \\
\hline
\end{tabular}


جدول V: عوامل شكل دهنده به "هويت مكانى" در سازمانيابى شهر اسلامى

Table 7: Factors Shaping "Spatial Identity" in Organization of Islamic City

\begin{tabular}{|c|c|c|c|c|}
\hline \multicolumn{4}{|c|}{ عوامل شكلدهنده } & \multirow{7}{*}{ هويتى } \\
\hline \multicolumn{3}{|c|}{ 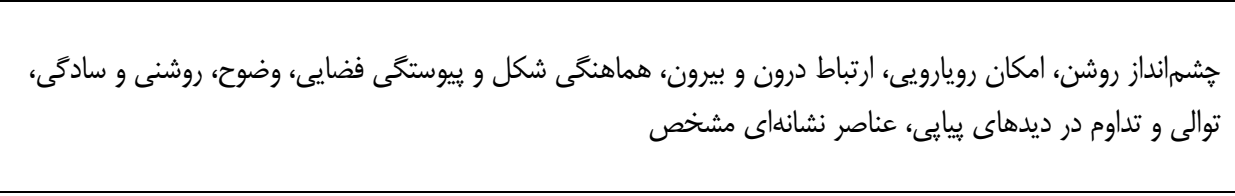 } & بيكره و سيما بهنهانداز & \\
\hline \multicolumn{3}{|c|}{ تناسب، قلمرو، تركيب، - عملكردى، نظهم ادراكى، گروهى ديدن عناصر همخوان، محصور كردن فضا، ايستايى و يويايى، مقياس و } & نظمم فضايى & \\
\hline 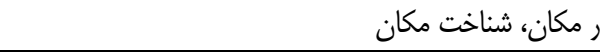 & اعى، نياز، حض & سلسلهمراتب فضايى، باورهاى فردى و & 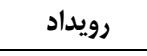 & \\
\hline خودا،، خودانخيختخى، امنيت عاطفى و كالبدى & كسترش مفهو & مكانهاى فردى در كنار مكانهاى ج & هويت فردى & \\
\hline توالى نشانهها جهت سنجش موقعيت، وضوح مسير حركت & جهت & \multirow{2}{*}{ ملاحظات زيباشناختى، ريشى و هنرى، داشتن، } & \multirow{2}{*}{ 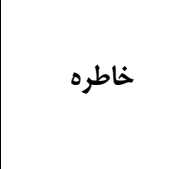 } & \\
\hline كاراكتر مشخص مكان، موتيفهاى معنادار در ييكربندى & 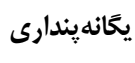 & & & \\
\hline
\end{tabular}

جدول م: راهبردهاى الكوبردارى هوشمندانه از لهويت مكانى" در بافت شهر اسلامى (با اقتباس از Chokhachian 2015, 58 ) Table 8: Clever modeling strategies of "spatial identity" in the context of Islamic city (Adapted from Hooshyar Yousefi and Chokhachian 2015, 58)

\begin{tabular}{|c|c|}
\hline توضيح & \\
\hline 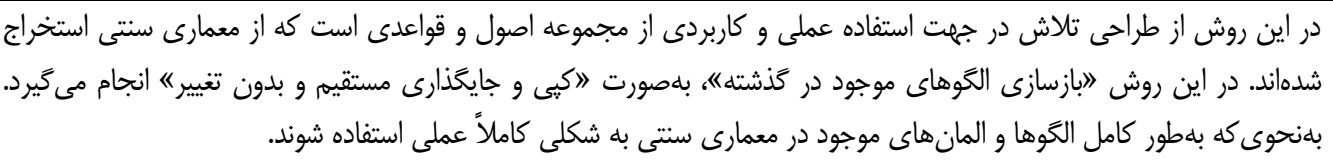 & راهب \\
\hline 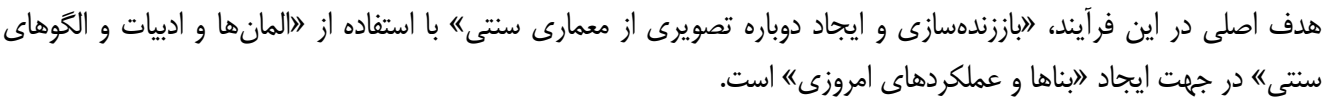 & مادين \\
\hline 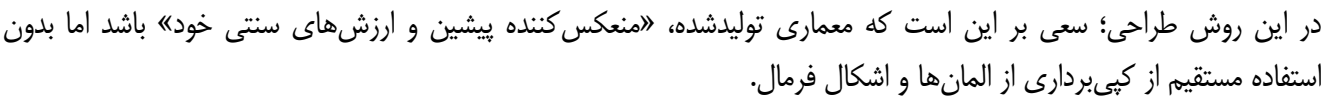 & مابهى \\
\hline 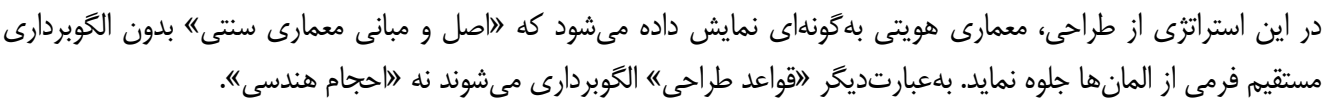 & \\
\hline 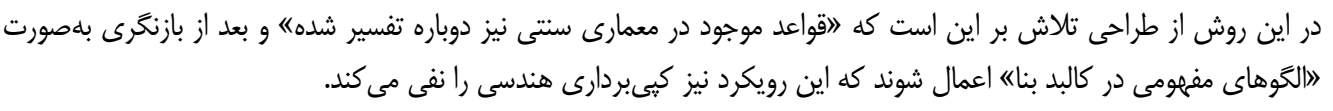 & راهبرد اختصارى يا \\
\hline در اين راهبرد، طراح بلهور عمدى طرح را از ااصول و مبانى سنتى" جدا ساخته و بلنوعى تلاش در به النمايش كذاشتن تجربياد & استعارى \\
\hline
\end{tabular}

موجود، فرصتهاى بيشترى را بيش رو دارند تا بتوانــد آثـار خلاقانه و نابترى را به وجود آورنسد و بـهـور آكاهانـه در

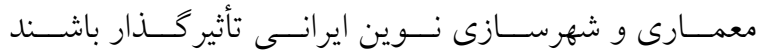

.(Hooshyar Yousefi \& Chokhachian 2015, 58- 59)

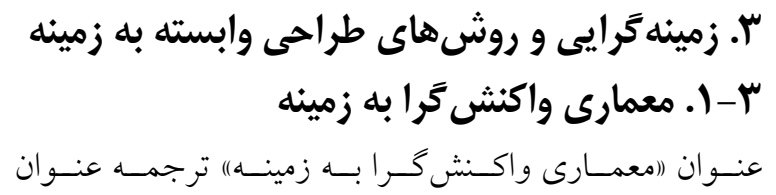

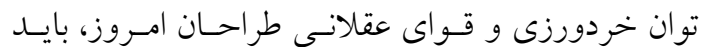
بيش ازييش، از محسدوديتهــاى دسـتويـا كيــر و باورهـاى

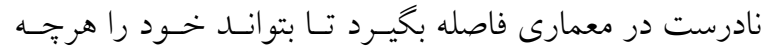
بيشتر دركير مباحـث و مطالعـات فرهنخـى كنـــ ايسن بـاور، امروزه به ضرورتى تبديلشده تا بتـوان بـا اسـتفاده منطقـى از دادههاى بومى به معمـارى قابـل قبـول در سـطح بـين المللى

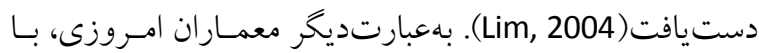
يسـيشزمينـههـاى فرهنخـى و باورهـاى متفـاوت بـا امكانـات 
بازشناسى الكوها و رويههاى معمارى زمينهَّا در انديشه و شهرهاى اسلامى در عصر جهانىسازى

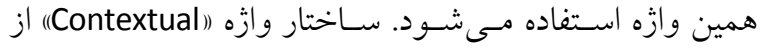

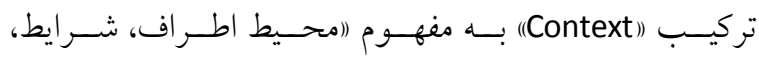
محيطزيست، بسزمينه)) و يا (تنظيماتى كه معناى يك رويــاد

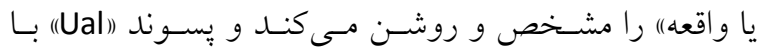
مفهوم كلى "(از نوع، مربوط به، داشـتن فـرم و يـا شخصسيت)

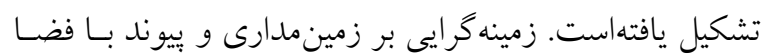

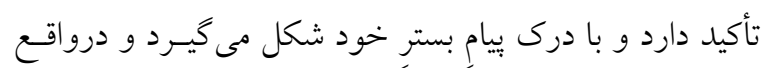

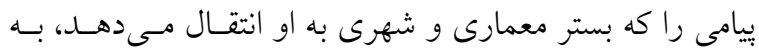

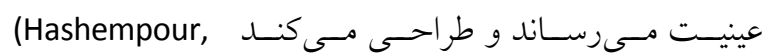
Nezhadebrahimi, \& Yazdani 2018, 109) بينشى فلسفى است كه هر رويدادى را بهمثابه عملى لاينفـى

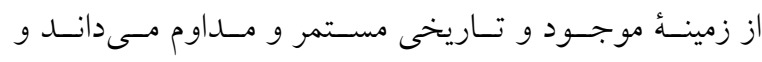
رويكردى كاركردى و بنيادگر ايانه دربـاره حقيقـت و معنـا در نظر گرفته مى شود. ريشهُ استعارى زمينه گرايى (اعمل در زمينه (Act in context) (است. ملاكى و معيار حقيقسى زمينـه گرايسى (Act) J.Fox, 2008, 55 Quoted by ( كار موفق يا عمل مؤثر) است Pirbabaei \& Molaei 2016, 108

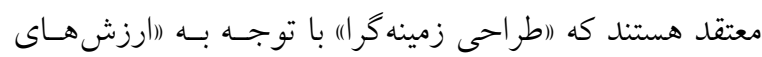
يك زمينه) به دو شيوه صورت مى گيرد كه عبـارتانـد از: ()

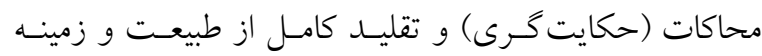
(أركانيك)؛ r) ارزيـابى ارتبـاط فيزيكسى و توصسيفات فُرمـال

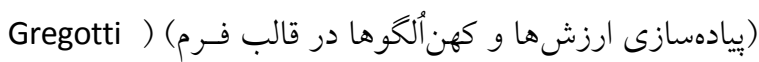
et al. 1992 Quoted by Babaei and Khakzand 2019, 176). بر اساس اين تقسيمبندى، اولين مورد، (ازمينه)) را مولـد و شكل دهندهُ تماميت يك اثر مى داند و دومين مورد، بهعنوان يك (مكان) بسترساز ايدههاى معين، بر اساس شبكة ارزشهـا

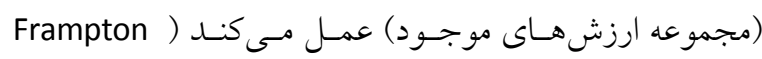
1995). نظريهيردازان زمينه گرايسى، ايسن موضسوع را در جهـار

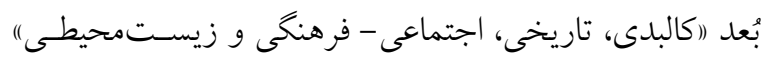
بررسى مى كنند (جداول شماره 9 و • (1).
(Responses to Site»)

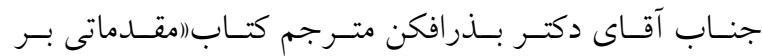
روش هاى طراحى)، تحت عنوان((و اكنش هايى به بستر)" ترجمه

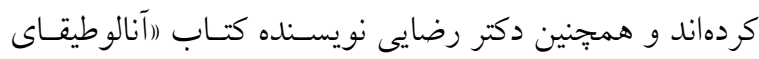
طراحى)، ايشان نيز با عنوان(اواكنش به بسـتر) ترجمـه و بيـان

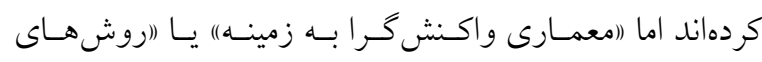
طراحى وابسته به زمينه) )جيست؟ در پِاسخ به اين سؤال ازنظر

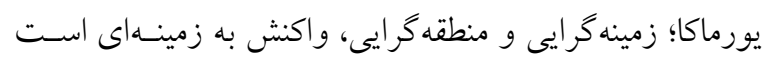

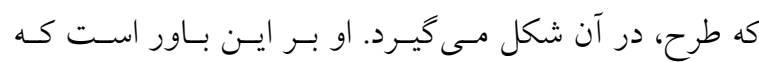
زمينه گرايى شيؤ ديخر يافتن راهحل طراحى بر اساس مستن و و

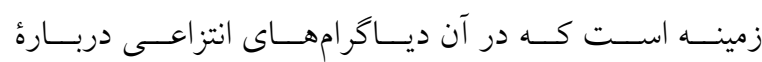
ريخت شناسى محيط، ترسيم و تلاش مسى شـود بـا تركيـب و

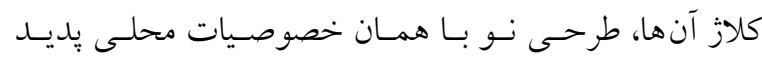

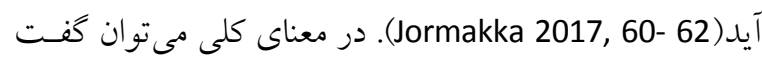

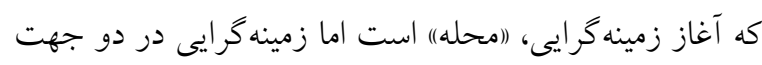

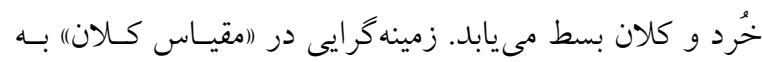

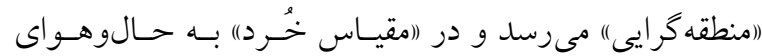
(ادرونى بنا) مىرسد. اما وجه جهانى منطقه كرايسى نيـز از حــــ منطقه فراتر رفته و بُعدى جهانى مى يابد و به (معمارى يايدار)) مىرسـد (Sayyadi, Maddahi, \& Mohammadpour 2011)؛ بدينسان معمارى زمينه گرا خود را اخرجه عميقاً در مكان فرو مىبرد اما حضور خود را تا دوردستها تا شهرها و كشـورها تا جهان و كيهان برمىافـرازد. تمركـز ايسن بــروهش نيـز، بـر زمينهكرايى در تفكر و انديشه اسلامى است.

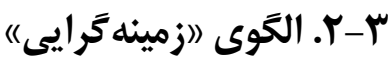

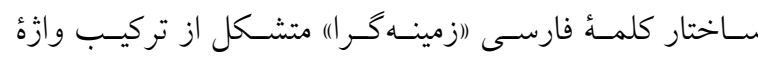

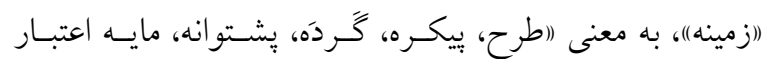

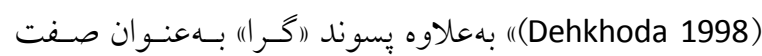

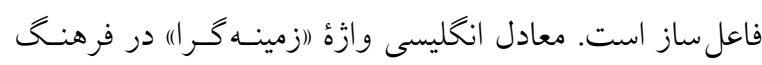
آريانيور، (Contextual) است كـه در متـون تخصصسى نيـز از 


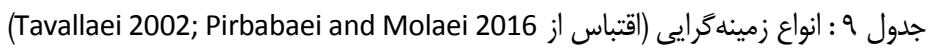

Table 9: Types of contextualism (Adapted from Tavallaei 2002; Pirbabaei \& Molaei 2016)

\begin{tabular}{|c|c|c|c|}
\hline ديدكاه & 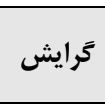 & متعهد & 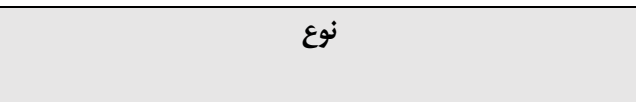 \\
\hline 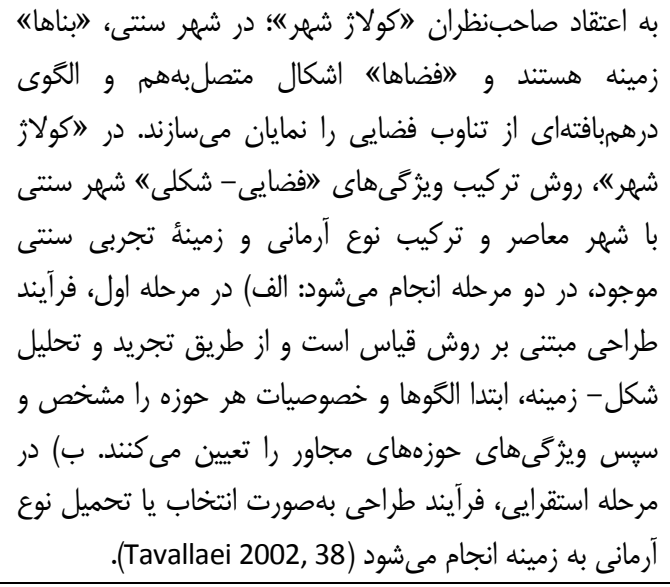 & & 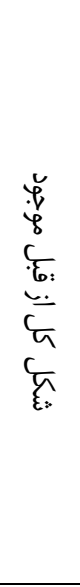 & 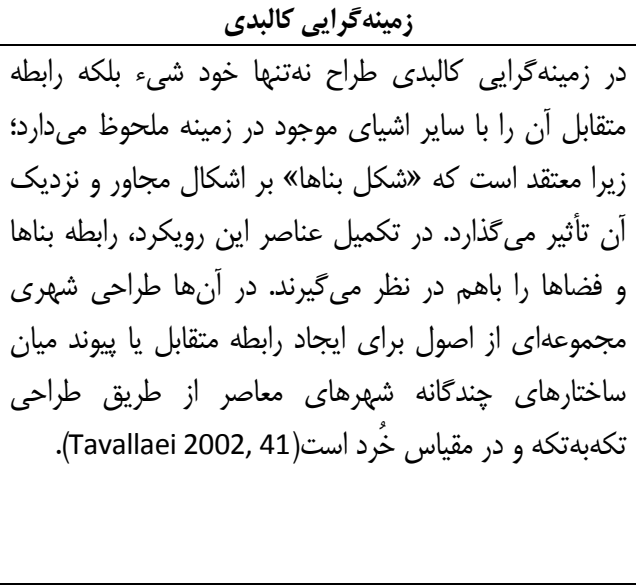 \\
\hline سنت گرايى از سيماى شهر گذشته الهام مى گيرد و بر اين باور & & & زمينهكرايى تاريخى \\
\hline 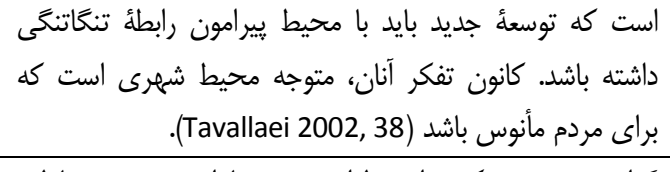 & & & 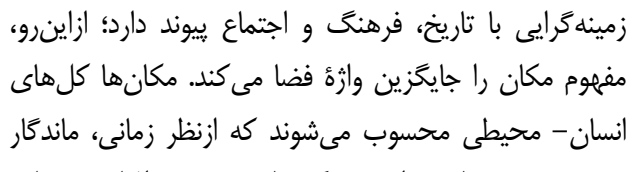 \\
\hline 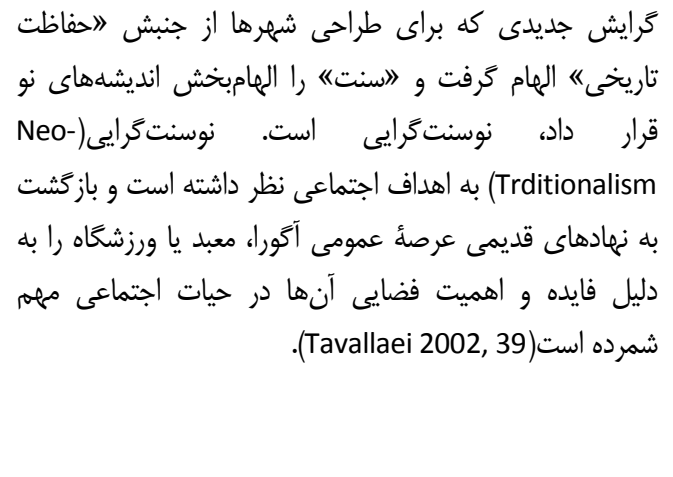 & $?$ & 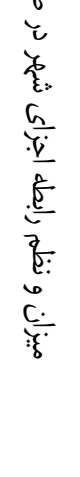 & 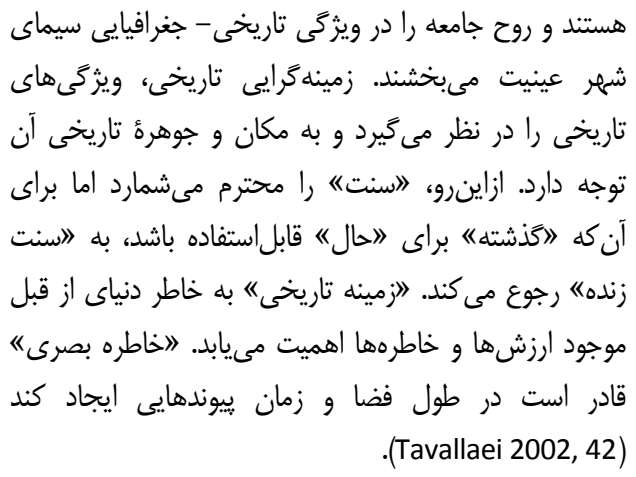 \\
\hline 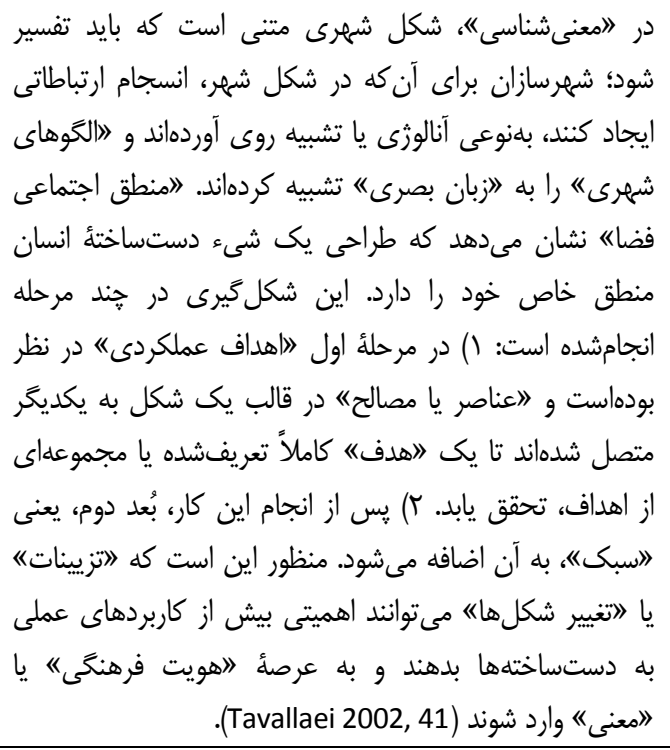 & & 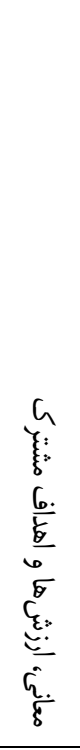 & 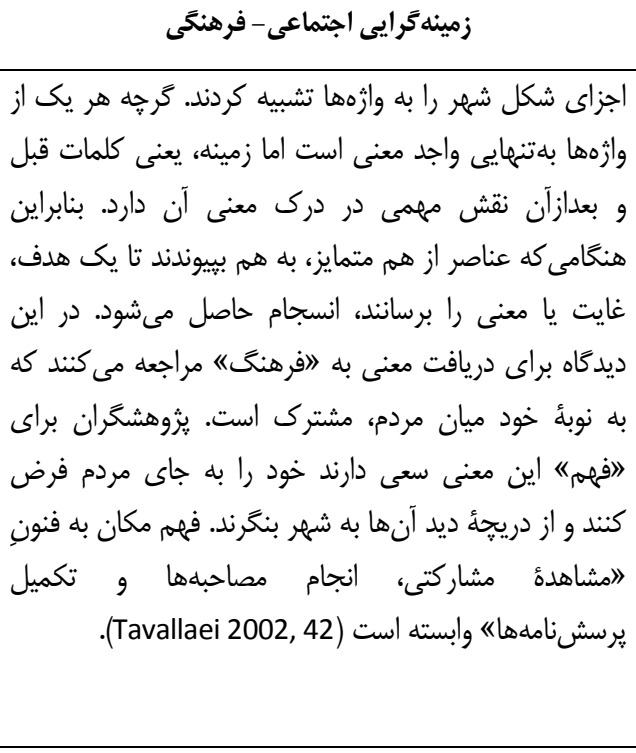 \\
\hline
\end{tabular}


بازشناسى الكوها و وويههاى معمارى زمينهكَرا در انديشه و شهرهاى اسلامى در عصر جهانىسازى

\begin{tabular}{|c|c|c|c|}
\hline 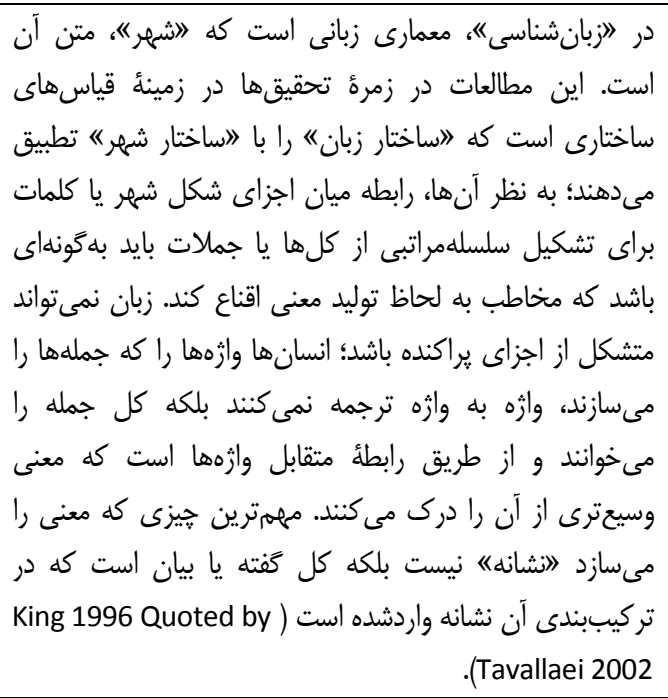 & 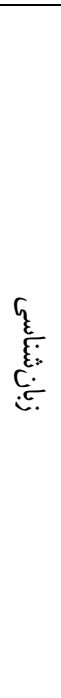 & & \\
\hline \multirow[b]{2}{*}{ 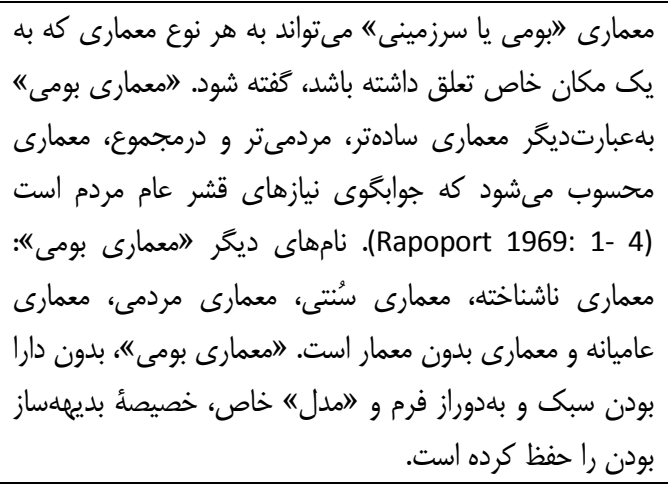 } & \multirow[b]{2}{*}{ 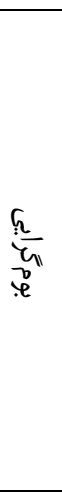 } & \multirow{3}{*}{$\begin{array}{l}q \\
q \\
\delta \\
a \\
q \\
q \\
: 6 \\
q .\end{array}$} & زمينه كر ايى زيستمحيطى \\
\hline & & & \multirow[t]{2}{*}{ 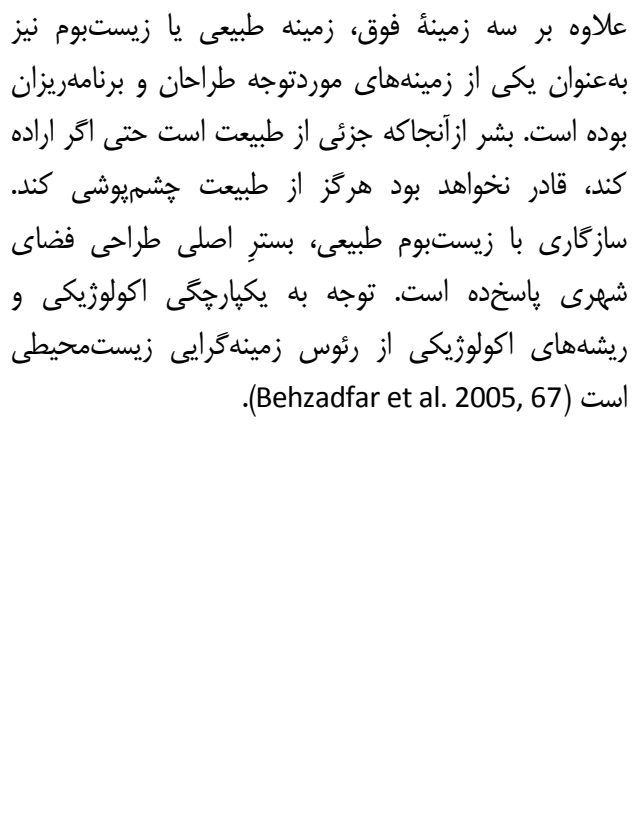 } \\
\hline 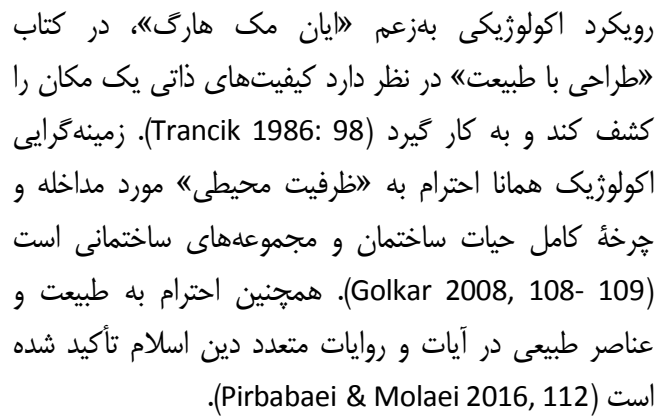 & $\begin{array}{l}\hat{n} \\
\underline{w} \\
\underline{w} \\
\underline{q} \\
\frac{q}{q}\end{array}$ & & \\
\hline
\end{tabular}

جدول • (: مؤلفهها و زيرمؤلفهاى انواع زمينهكرايى (Hashempour, Nezhadebrahimi, \& Yazdani 2018)

Table 10: Components and sub-components of a variety of contextualism(Hashempour, Nezhadebrahimi, \& Yazdani 2018)

\begin{tabular}{|c|c|c|c|}
\hline \multicolumn{2}{|l|}{ زيرمؤلفها } & مؤلفهها & نوع \\
\hline عرض معابر و درجهبندى شبكه دسترسى سواره & \multirow{8}{*}{ شبكه دسترسى (معابر و كها) } & \multirow{9}{*}{$\begin{array}{c}\text { (فضاى مابين) } \\
\text { فضا }\end{array}$} & \multirow{9}{*}{ 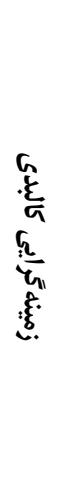 } \\
\hline نسبت عرض به ارتفاع در معابر & & & \\
\hline الكَوهاى سلسهمراتبى در شبكه دسترسى سواره & & & \\
\hline الكوهاى سلسهمراتبى در شبكه دستر سى يبياده & & & \\
\hline الكوهاى سلسهمراتبى در محل اتصال شبكه سواره و يياده & & & \\
\hline الكَوهاى سلسهمراتبى در محل اتصال شبكه سواره و كَرها & & & \\
\hline الكُوهاى سلسهمراتبى در محل اتصال شبكه يياده و يياده & & & \\
\hline | مصالح و كفسازى معابر و شبكههاى دسترسى & & & \\
\hline & كرّها و ميادين باز شهر & & \\
\hline
\end{tabular}




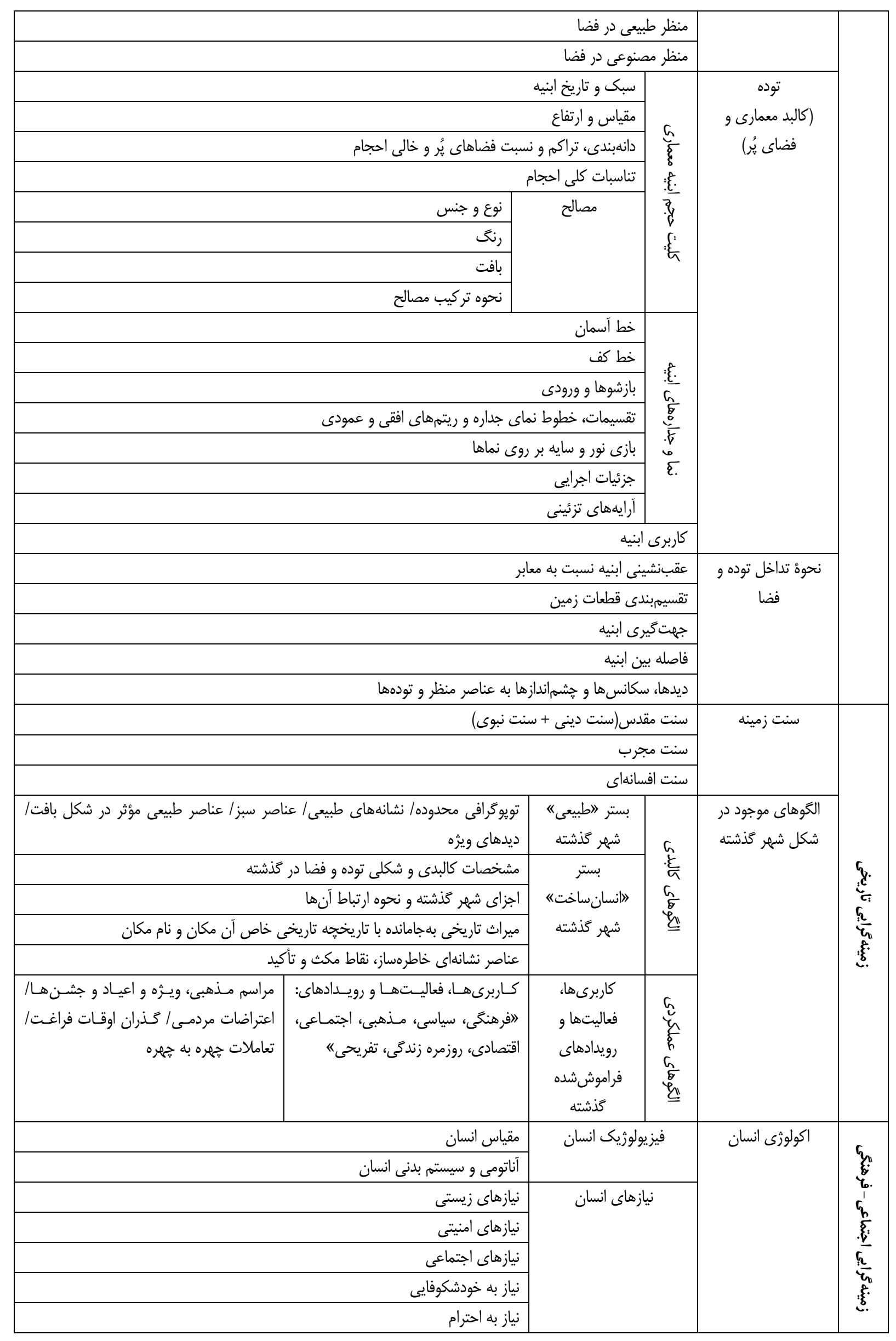


بازشناسى الكَوها و رويههاى معمارى زمينهمَرا در انديشه و شهرهاى اسلامى در عصر جهانىسازى

\begin{tabular}{|c|c|c|c|c|}
\hline معانى اشكال و بديدهها & \multirow[t]{2}{*}{ 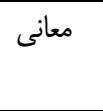 } & \multirow[t]{6}{*}{ فرهنگ انسان } & & \\
\hline | معانى حاصل از روابط بين بِيديدها & & & & \\
\hline \multicolumn{2}{|c|}{ ايدئولوزى، باورها، ارزشهاو جهانيينى } & & & \\
\hline \multicolumn{2}{|c|}{ دين و مذهب } & & & \\
\hline | حالات و رفتارهاى انسان & \multirow{2}{*}{ واكنش و } & & & \\
\hline | روابط متقابل اجتماعى & & & & \\
\hline \multicolumn{2}{|c|}{ ارتفاع از سطح دريا } & \multirow{3}{*}{ مشخصات اقليمى زمينه } & \multirow[t]{24}{*}{ كليماتولوزى } & \\
\hline & & & \\
\hline \multicolumn{2}{|c|}{ طول جغرافيايى } & & & \\
\hline \multicolumn{2}{|c|}{ ميانكَين حداقل و حداكثر درجه حرارت در سال، در ماه، در شبانهروز } & درجه حرارت & & \\
\hline \multicolumn{2}{|c|}{ موقعيت خورشيد } & نور خورشيد & & \\
\hline \multicolumn{2}{|c|}{ زاويةٔ حركت خورشيد در فصول } & & & \\
\hline \multicolumn{2}{|c|}{ شدت تابش خورشيد } & & & \\
\hline \multicolumn{2}{|c|}{ تعداد روزهاى آقتابى در سال } & & & \\
\hline \multicolumn{2}{|c|}{ تعداد روزهاى يخبندان در سال } & & & \\
\hline \multicolumn{2}{|c|}{ رطوبت مطلق } & ر رطوبت هوا & & \\
\hline \multicolumn{2}{|c|}{ رطوبت مخصوص } & & & \\
\hline \multicolumn{2}{|c|}{ رطوبت نسبى } & & & \\
\hline \multicolumn{2}{|c|}{ فشار بخار } & & & \\
\hline بادهاى تجارى & \multirow[t]{6}{*}{ انواع باد } & \multirow[t]{10}{*}{ باد و جريان هوا } & & s \\
\hline 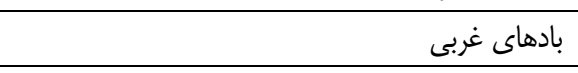 & & & & \\
\hline بادهاى قطبى & & & & $c$ \\
\hline بادهاى موسمى & & & & $\frac{2}{n_{n}}$ \\
\hline بادهاى محلى & & & & \\
\hline نسيههاى دريا و خشكى & & & & \\
\hline \multicolumn{2}{|c|}{ جهت وزش بادهاى غالب در فصول سال } & & & \\
\hline \multicolumn{2}{|c|}{ سرعت وزش بادهاى غالب در فصول سال } & & & \\
\hline \multicolumn{2}{|c|}{ فشار وزش بادهاى غالب در فصول سال } & & & \\
\hline \multicolumn{2}{|c|}{ | تعداد دفعات وزش بادهاى غالب در فصول سال } & & & \\
\hline \multicolumn{2}{|c|}{ نوع بارندگى غالب } & \multirow[t]{2}{*}{ 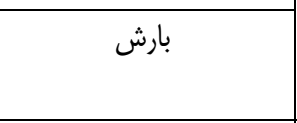 } & & \\
\hline لـاقل و حداكثر بارندَّى در سال، ماه و شبانهروز & 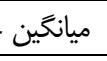 & & & \\
\hline & & آبهاى جارى سطحى & هيدرولوزى & \\
\hline & & آبهاى زيرزمينى & & \\
\hline & & شكل ناهموارى هاى زمين & رئومورفولوزى & \\
\hline & & جهت و مقدار شيب زمين & & \\
\hline & & جنس خاك & & \\
\hline & & يوشش كياهى غالب & & \\
\hline
\end{tabular}

فرهنخِ معمارى و شهرسازى اسلامى - سال ينجم، شماره اول- بهار و تابستان 99 


\section{ץ-ع. شاخصهايى جهت حفظ و ارتقاى ارزش هاى موجود در معمارى زمينه كَرا}

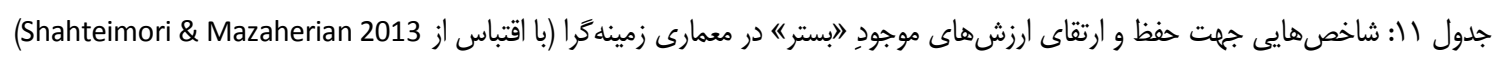
Table 11: Indicators for preserving and enhancing the existing 'context' values in contextual architecture (Adapted from Shahteimori \& Mazaherian 2013)

\begin{tabular}{|c|c|c|}
\hline دتوجه & توضيح & خص \\
\hline فرهنگىى، اجتماعى، & 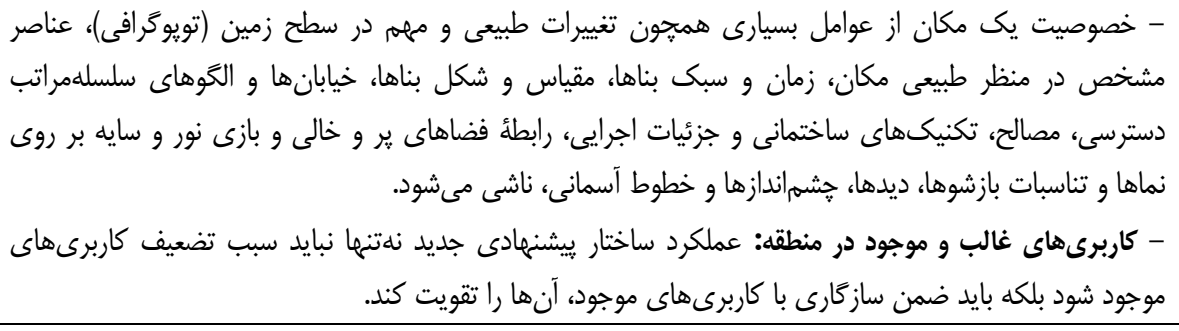 & 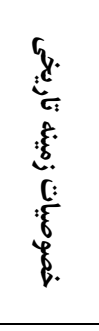 \\
\hline 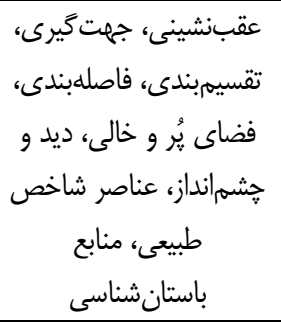 & 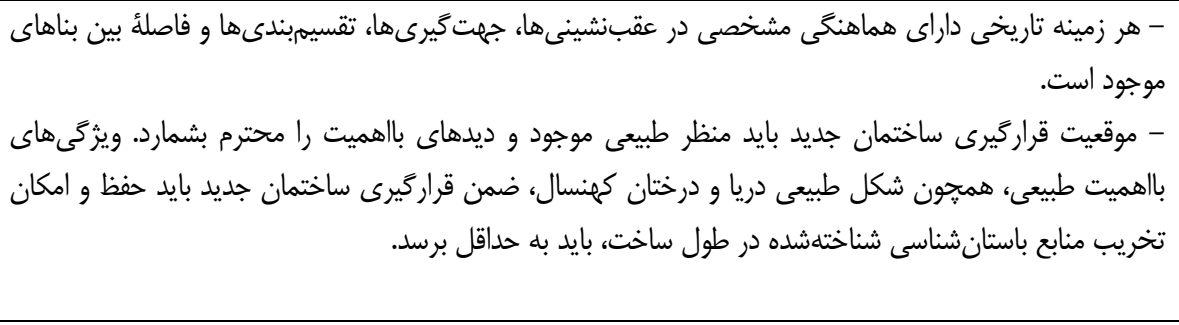 & 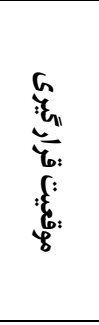 \\
\hline 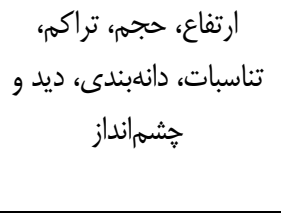 & 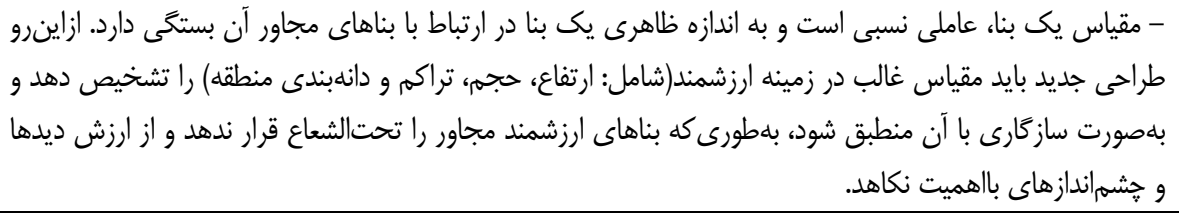 & \\
\hline 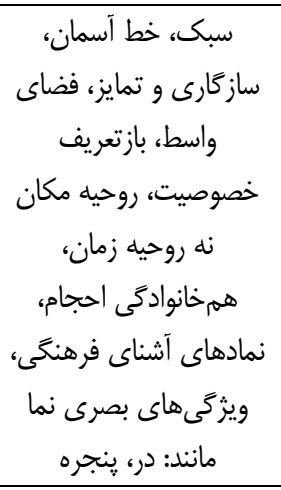 & 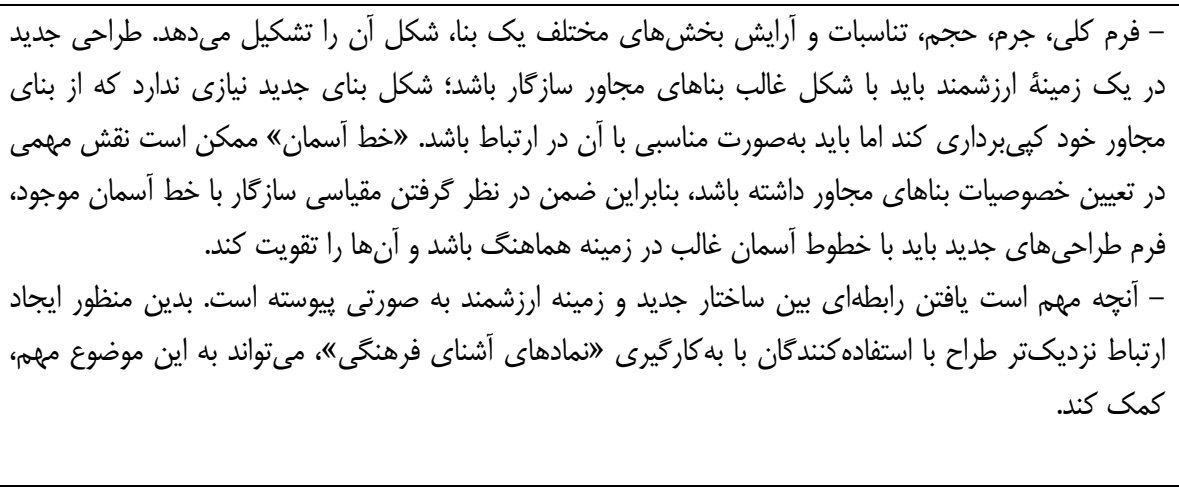 & है. \\
\hline 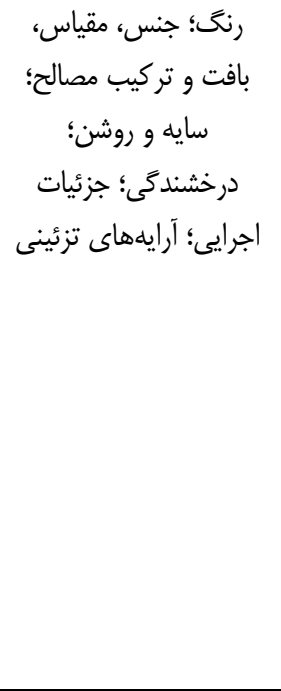 & 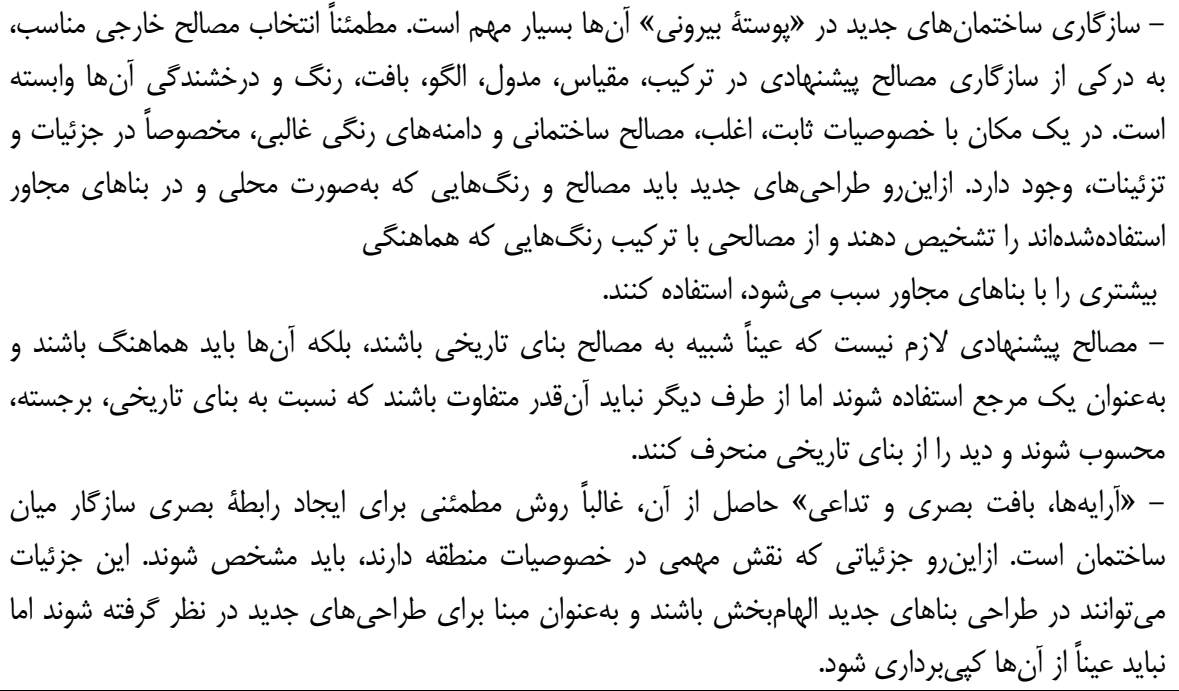 & 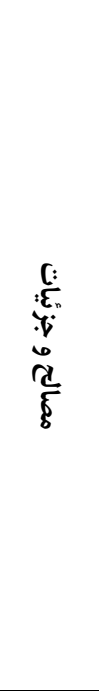 \\
\hline
\end{tabular}




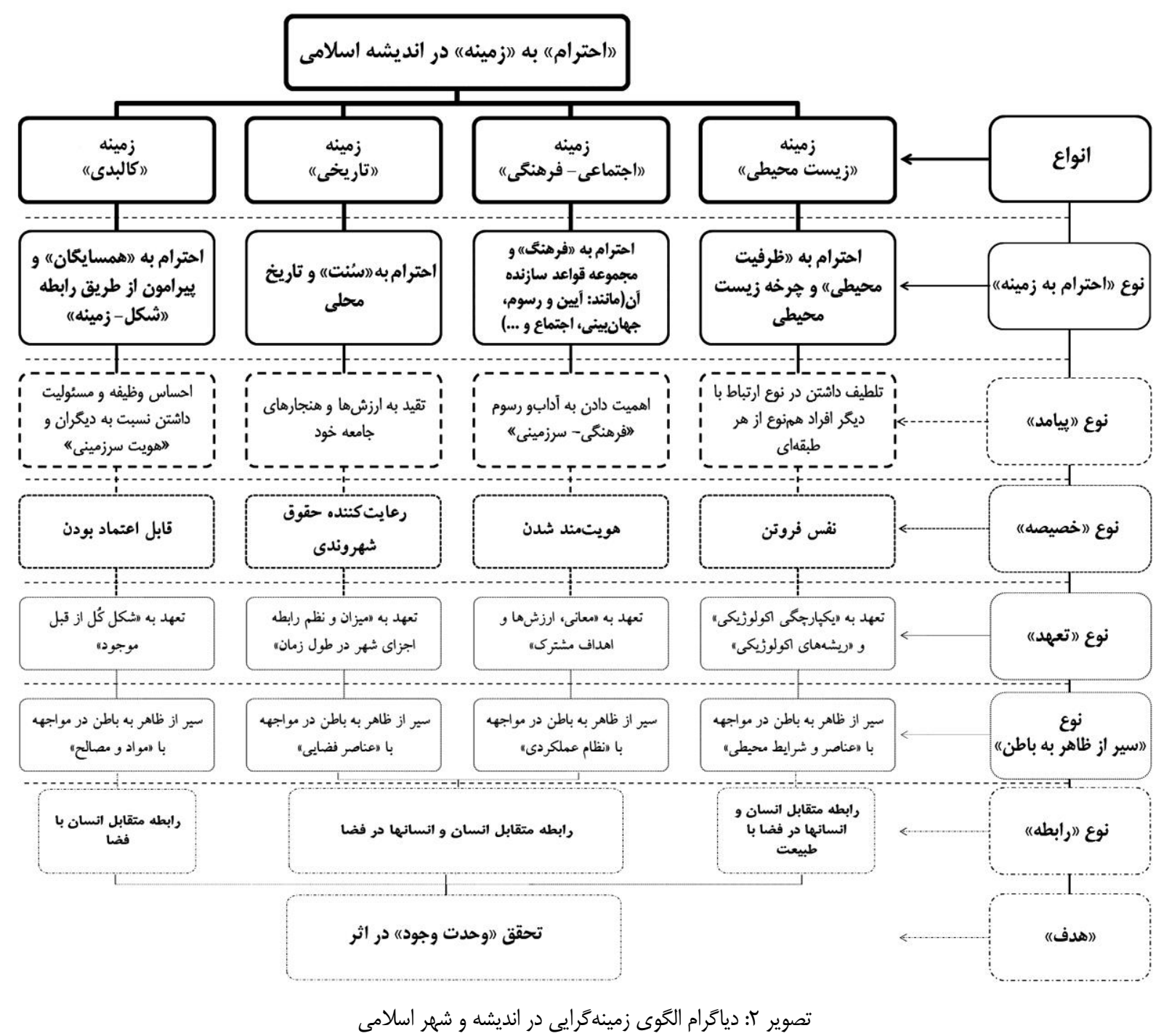

Fig. 2: Contextualism pattern diagram in thought and Islamic city

مى كند؛ گيرندهُ بيام نيز متن را با توجه به آموزههاى رمـزين و ذهنى خود، رمز گشايى يا رمزشكنى مى كنــد. او بيـام را از راه

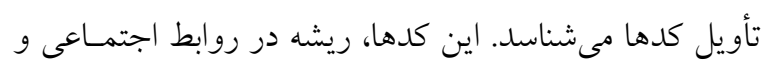

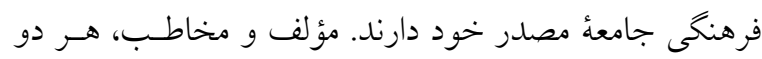

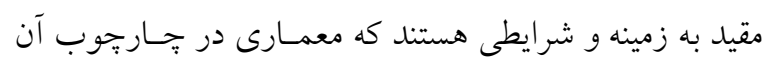

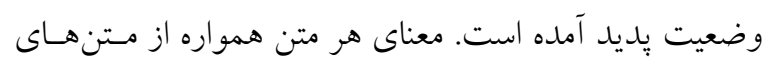
از بيش موجود آنكه به غياب راندهشدهاند، دريافت مىشود. ازاينرو براى درك كاملتر از موضوع، توجه به الكوها و فرآيندهاى طراحى كه توسط (معماران باتجربـه و داراى فكـر صحيح) ساخته مىشود؛ يكى از راههاى دستيابى به ريشههاى اجتماعى و فرهنكى جامعهُ معاصر است، زيرا اين بروزهها، از الكوهاى ساده و بردوامى تبعيت مى كند كه از فرهنگ، عقايد،
ع. تحليل و بحث در بازشناخت يك اثر معمارى سه كونـه فضـاى متفــاوت در

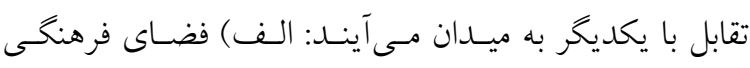
شخص سازنده بنا، ب) فضاى فرهنكى شخصى كـه بـه بنـا مىنخرد و ج) فضاى فرهنگى شخصى كه يافتهاى اظهارشده

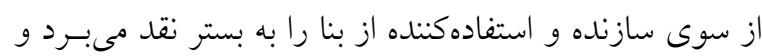

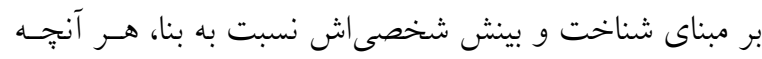
را از ماهيت اثر درمى يابد، براى شخص جهـارمى بـهـ نمـايش

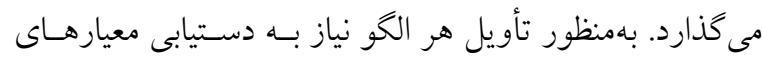

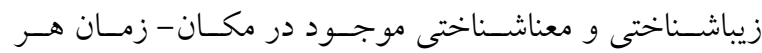
متن(معمارى) اجتنابنايذير است. زيرا مؤلف، هر مستن را بـاـ توجه به قراردادها و در حيطهُ ادبيات جامعهُ خود، رمزگـذارى 
جهانى سازى(يكسانسازى) بهمنظور دستيابى به منشـأ واحــ، اصول راهنما و رهنمودهاى اجرايى، جهت استـفادئ طراحسان بهمنظور طراحى ساختمانهاى جديد در زمينها و بافتهـاى

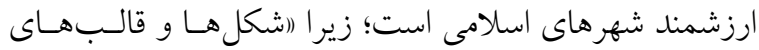

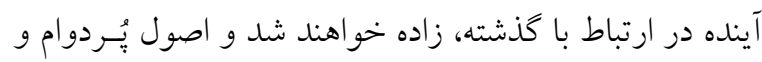
تكرارشوندة كذشته باتجربه و بيسـش جديـد، صـورت نـوين خود را خواهند يافت).
طبيعت و روشهـاى زنــدى جامعـه سر خشـمه كرفتـهـــهـ

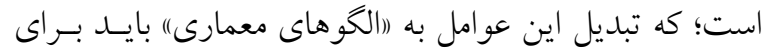

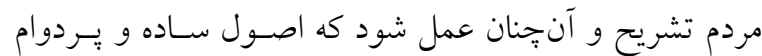

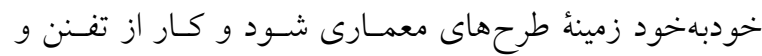

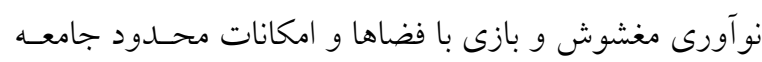

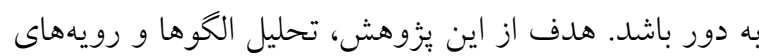
"(معمارى زمينه گرا در انديشه و شـهرهاى اسـلامى) در عصـر

\section{نتيجه كيرى}

سنجش است. صورت هنر اسـلامى، محملـى بـراى شـناخت

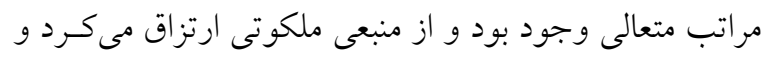

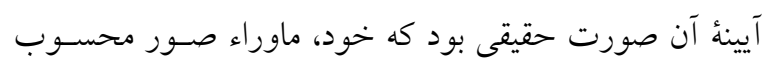

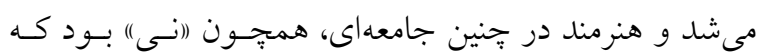

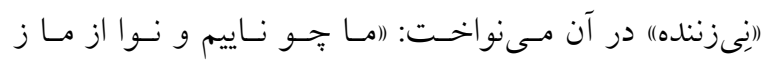

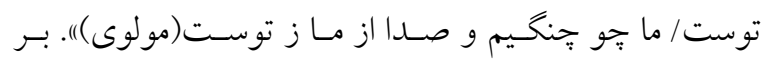
اساس ديدكاه يزوهشكر ان حوزهُ معمـارى اسـلامى در ايـران،

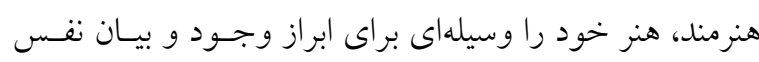

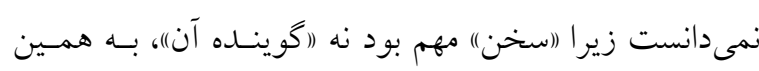

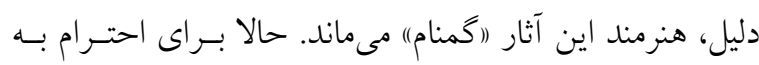

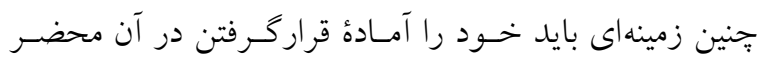

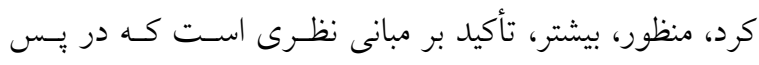

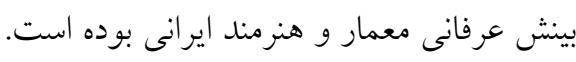

(فرهنگ دينى)، روح زيبا را زاينـدة زيبـايى و روح زشـت را

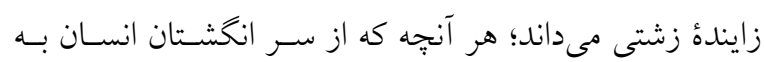
منصه ظهور مىرسد، تجسمى از شخصيت ينهانى و تبلـورى

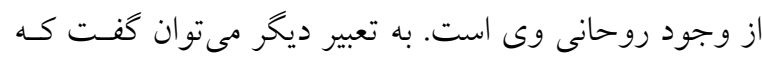

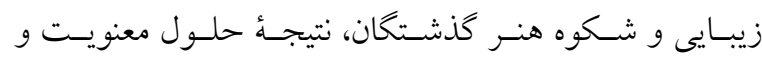

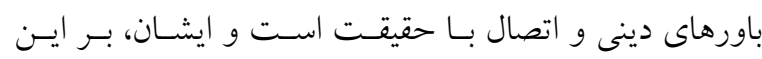

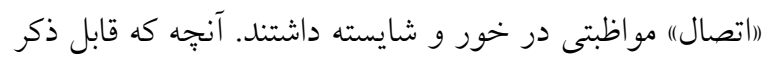

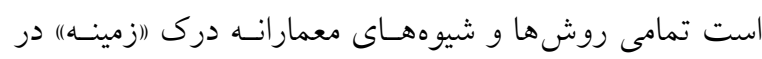

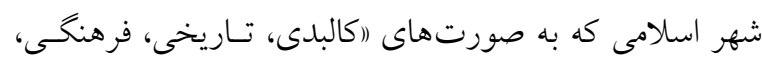

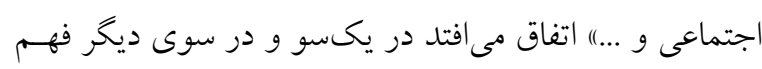
بينش شكل دهنده به ايـن نـوع معمـارى و شهرسـازى، حسائز

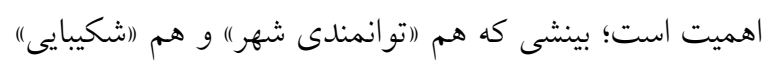

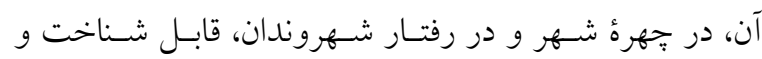

\section{فهرست منابع}

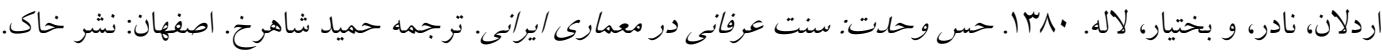

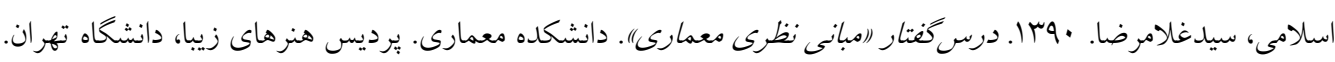

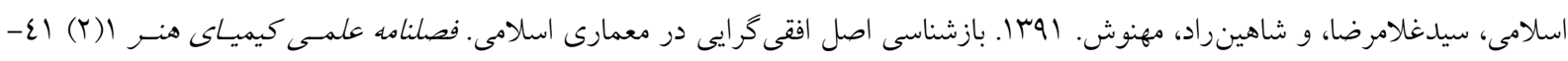

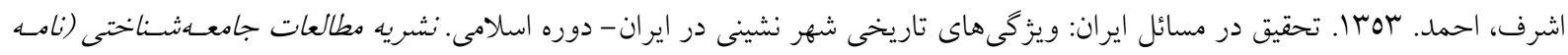

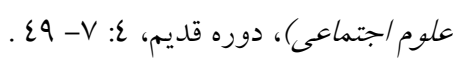

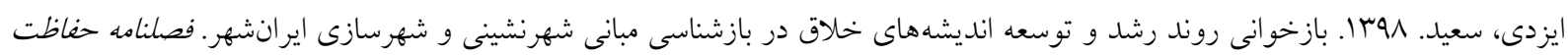

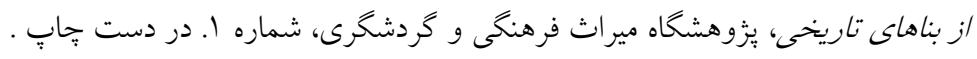

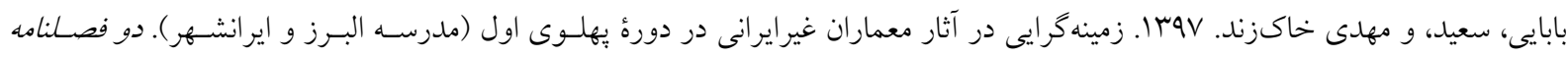


بازشناسى الكَوها و رويههاى معمارى زمينهمَرا در انديشه و شهرهاى اسلامى در عصر جهانىسازى

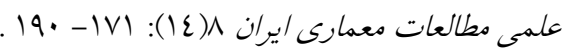

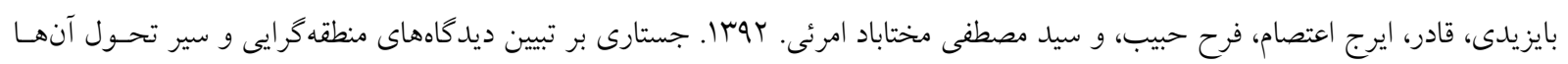

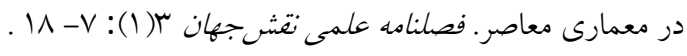
بذرافكن، كاوه، على اكبر اكبرى، فرهاد تهرانى، و حسين سلطانزاده.

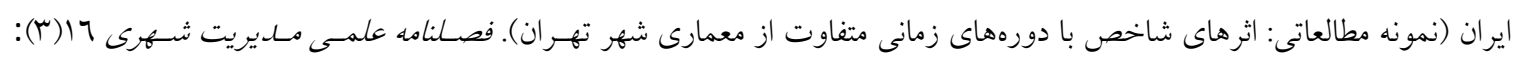

rer TrTV

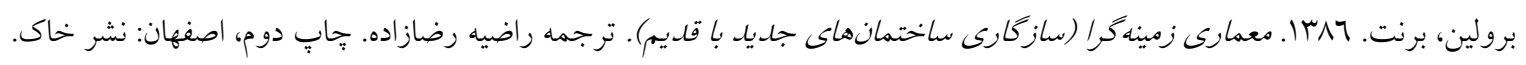

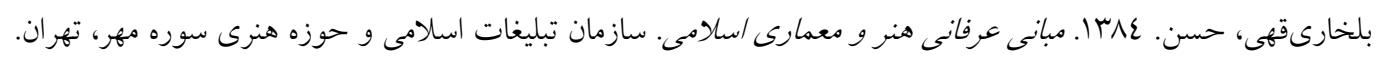

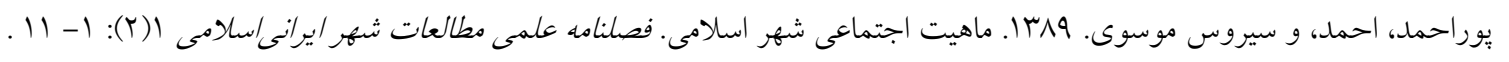

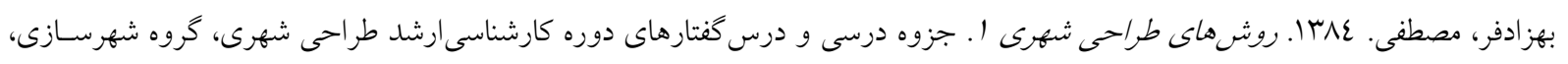

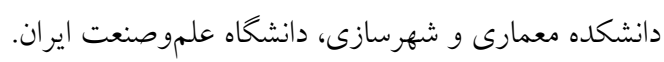

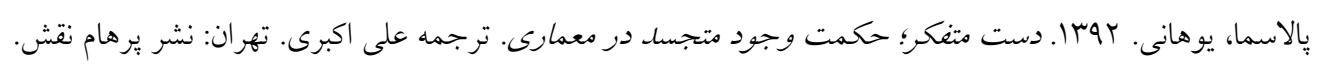

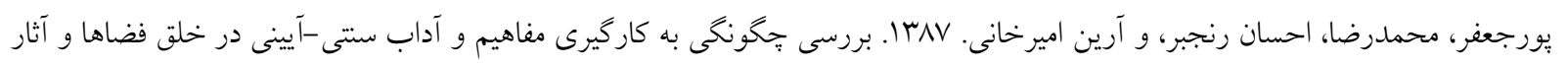

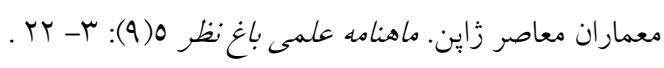

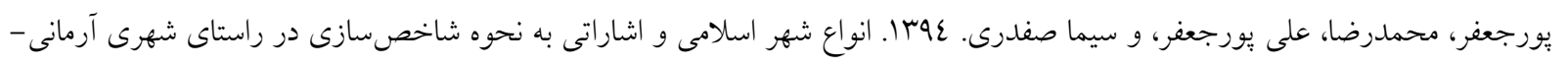

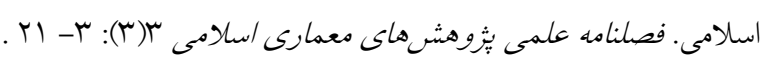

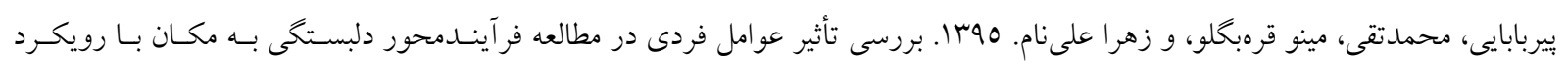

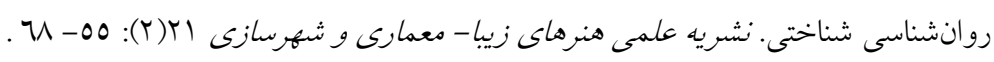

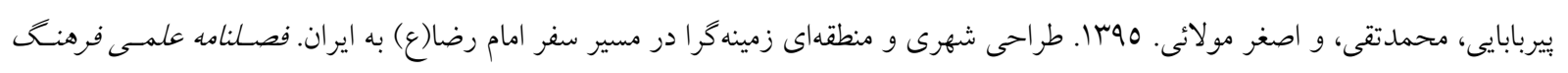

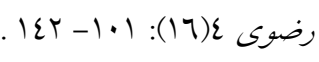

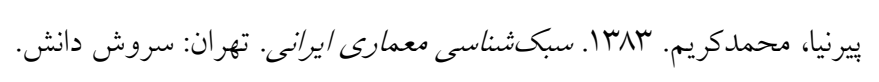

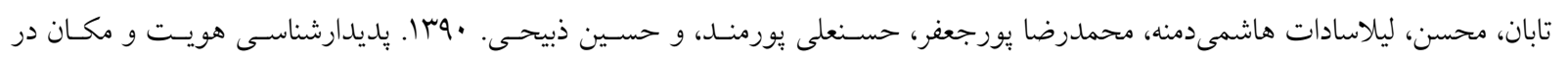

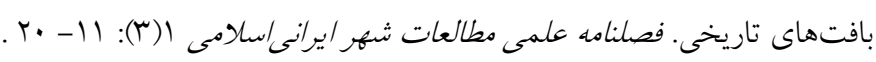

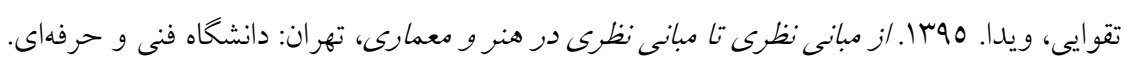

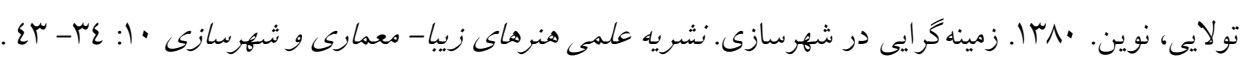

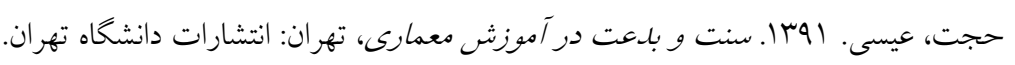

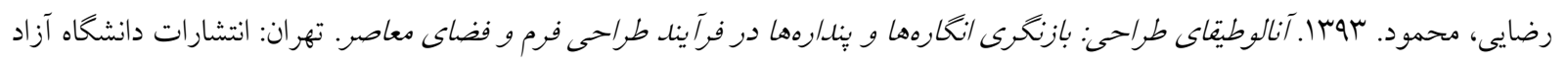

$$
\text { اسلامى واحد تهران مركزى. }
$$

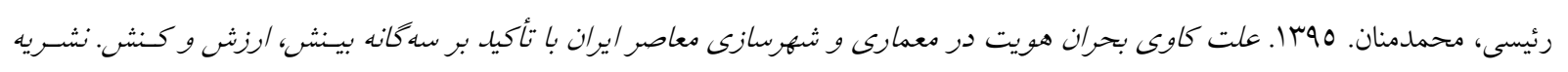

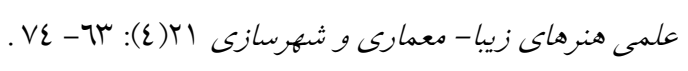

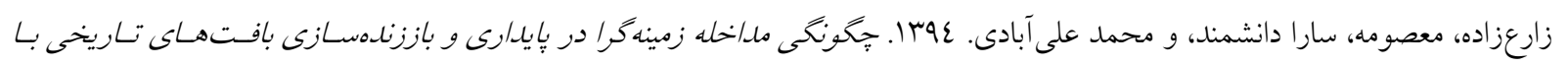

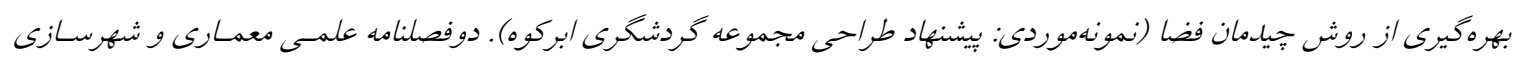

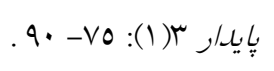

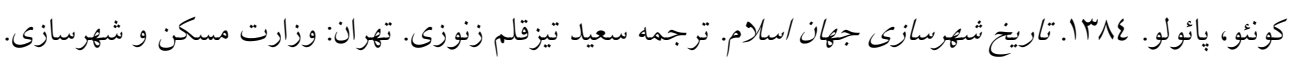

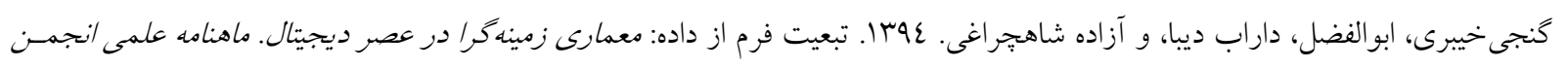

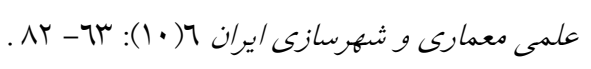

كالكار، كورش. 


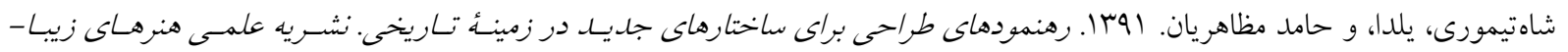

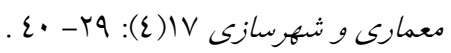

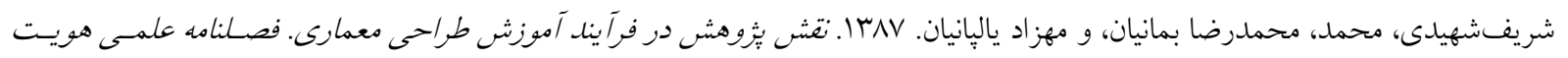
. 9 r-1 : شهر

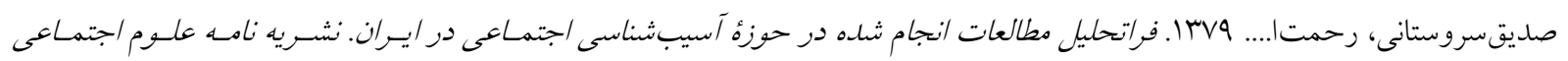
. $1 \cdot r-7 V:(10) 10$

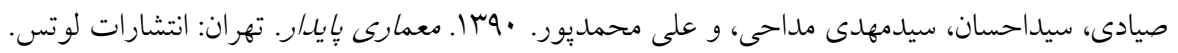

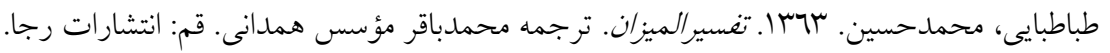

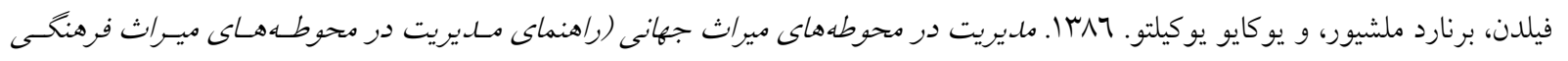
جهان). ترجمه بيروز حناجى. تهران: انتشارات دانشگاه تهران.

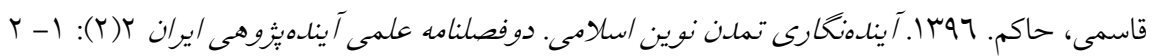

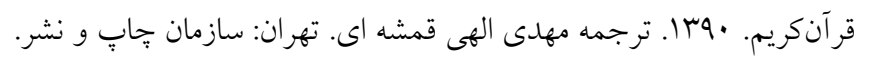

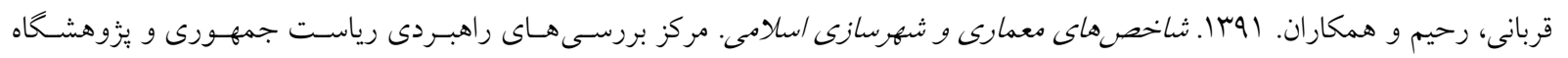
بين المللى المصطفى(ص)، تهران.

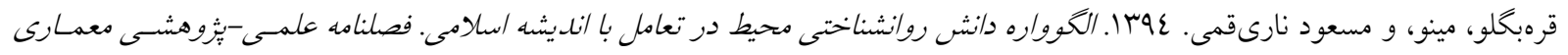

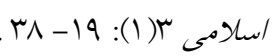

قرهبخلو، مينو، اميرحسين فرشخيان، و زهرا محمدعليان. 90با. تأثير و تأثيرات تعاملات اجتماعى بر خلق مكان در معمارى /سـلامى. ماهنامسه

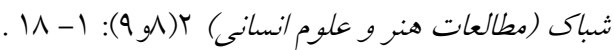

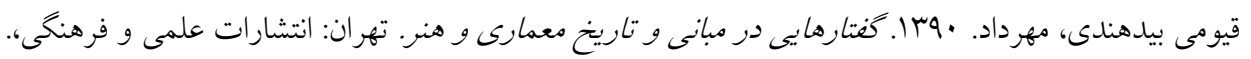

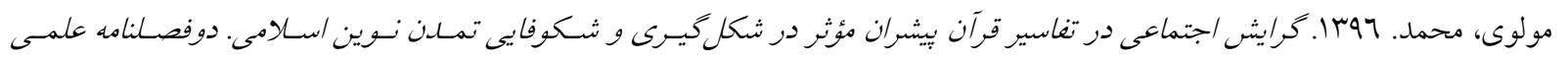

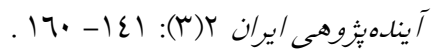

مرتضى، هشام. VNس ا. اصول ستتى ساختوساز در اسلام. ترجمه ابو الفضل مشكينى و كيومرث حبيسى. تهـران: انتشـارات مركـز مطالعـاتى تحقيقاتى شهرسازى و معمارى.

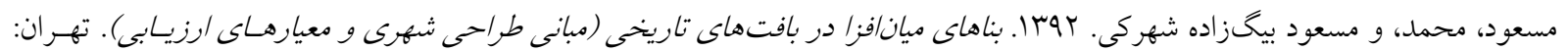
انتشارات آذرخش.

ميرباقرى، سيدمحمد مهدى. سوسا. هنر، دين، تجلدد، كفتارهايى در مبانى هنر. قم: انتشارات كتاب فردا.

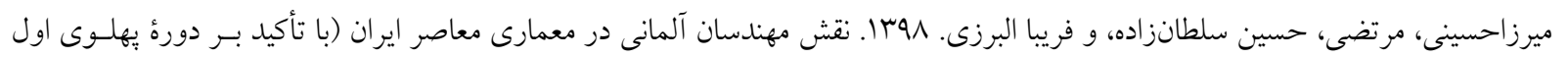

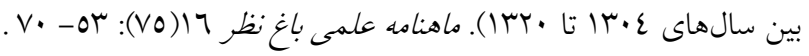

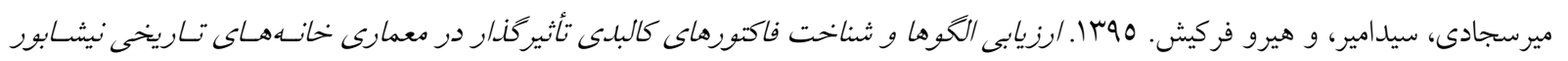

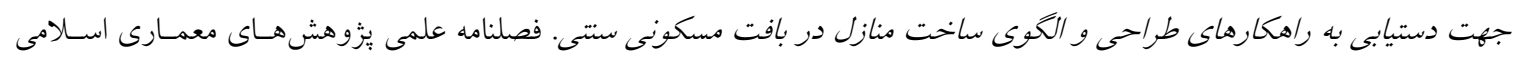
$.9 r-V T:(\varepsilon) \varepsilon$

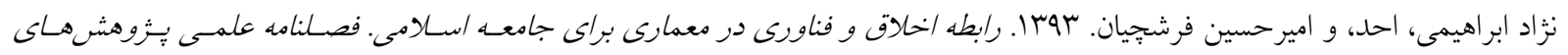

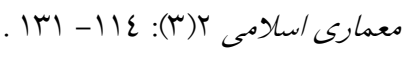
نصر، سيدحسين. ع9 إ. هنر و معنويت /سلامى. ترجمه رحيم قاسميان. تهران: انتشارات حكمت.

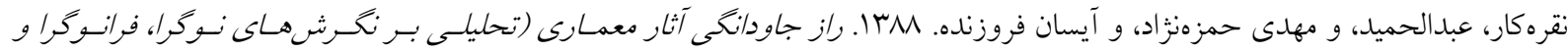

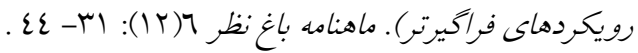

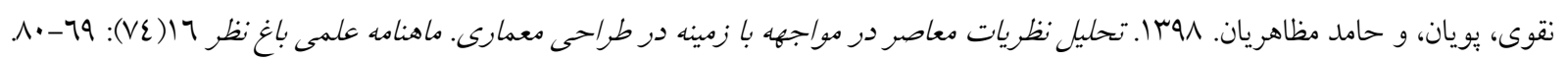


بازشناسى الكوها و رويههاى معمارى زمينهَّرا در انديشه و شهرهاى اسلامى در عصر جهانىسازى

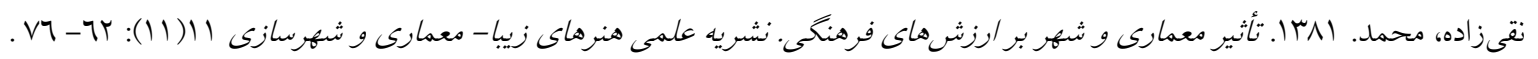

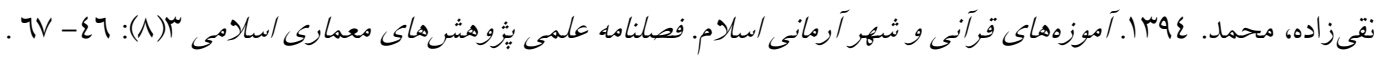

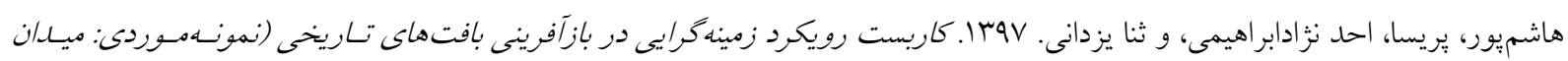

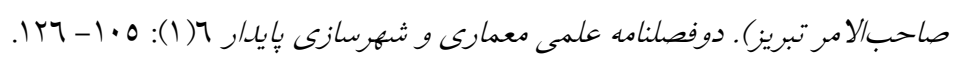

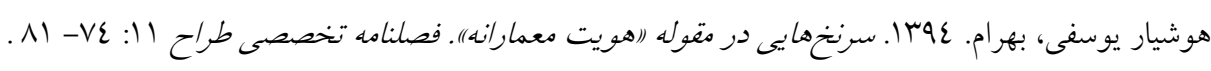

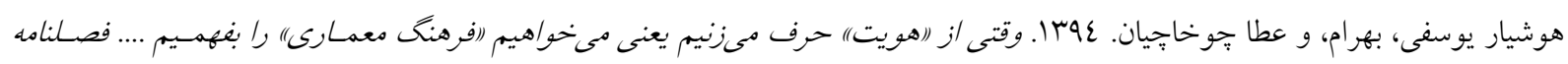

$$
\begin{aligned}
& \text { تخصصى طراح 11: }
\end{aligned}
$$

The Holy Quran. 2010. Translated by Mahdi Elahi Ghomshehei. Tehran: Printing and Publishing Organization.

Ardalan, N., Sert, J. L., Doshi, B., Safdie, M., and Candilis, G. 1976. Habitat Bill of Rights, Ministry of Housing. Persian: Imperial Government of Iran. [In Persian]

Ardalan, Nader., and Bakhtiar, Laleh. 2001. The sense of unity : the Sufi tradition in Persian architecture. Translated by Hamid Shahrokh. Isfahan: Khak Publishing. [In Persian]

Ashraf, Ahmad. 1975. Historical features of urbanization in Iran - Islamic period. Publication info Journal (4): 7-49. [In Persian]

Babaei, Saeid., and Khakzand, Mehdi. 2019. Contextualism in the Works of Non-Iranian Architects during the Pahlavi I Era Case Study: Alborz and Iranshahr Schools. Journal of Iranian Architecture Studies 8(14): 171-189. [In Persian]

Bayzidi, Q., Etesam, I., Farah, H., and Mokhtabad Amrei, S.M. 2013. Explanation of Regionalistic Viewpoints \& their Evolution in Contemporary Architecture. Journal of Naqshejahan (Basic studies and New Technologies of Architecture and Planning) 3(1): 7-18. [In Persian]

Bazrafkan, K., Akbari, A.A., Tehrani, F., and SoltanZadeh, H. . 2017. Conceptualism and Regionalism Planning Methods in the Iranian Architecture (Case Study: Distinctive Works of Different Eras in Tehran Architecture). Intenational Journal of Urban and Rural Management 16(48): 327-342. [In Persian]

Behzadfar, Mostafa. 2005. Urban Design Methods 1. Postgraduate Courses and Lectures in Urban Design, Department of Urban Planning, School of Architecture and Urban Planning, Iran University of Science \& Technology. [In Persian]

Bolkhari Ghahi, Hassan . 2005. Mystical Foundations of Islamic Art and Architecture. Tehran: Sooore Mehr Publishing Co. [In Persian]

Brolin, Brent C. 2007. Architecture in context: pitting new buildings with old. Translated by Rezazadeh. Second Edition. Isfahan: Khak Publishing.

Cumeo, Paolo. 2005. Storia dell urbanistica II mondo islamico. Translated by Saeed Tizghalam. Tehran: Civil and Rehabilitation Company.

Fazelian, S.M., and Eqbali, S. R. 2017. Lifestyle; the neglected element of Islamic architecture. Journal of Interdisciplinary Studies in the humanities 10(1): 57-80. [In Persian]

Feilden, Bernard M. 1998. Management guidelines for world cultural heritage sites. Translated by Piroz Hanachi. Tehran: University of Tehran Press(UTP).

Frampton, Kenneth. 1995. Studies in Tectonic Culture. Edited: John Cava. USA: Boston.

Ganji Kheibari, A., Diba, D., and Shahcheraghi, A. 2015. Form compliance with data: contextual architecture in the digital age. Journal of Iranian Architecture and Urbanism 6(10): 63- 82. [In Persian]

Golkar, K. 2008. Concptual Evolution of Urban Visual Environment; Form Cosmetic Approach Through to Sustainable Approach. Journal of Environmental Sciences 5(4): 95- 113. [In Persian]

Ghasemi, Hakem. 2018. Islamic Civilization in Transition; the Necessity of Foresight and Strategic Planning in Creating the New Islamic Civilization. Journal of Iran Futures Studies 2(2): 3- 21. [In Persian]

Ghorbani, Rahim. 2012. Indicators of Islamic Architecture and Urban Planning. Tehran: Presidential Strategic Studies Center and Al-Mustafa International Research Center. [In Persian]

Gharehbaglou, Minou., and Nari Ghomi, Masud. 2015. A Model of Environmental Psychology in interaction with Islamic thought. Journal of Researches in Islamic Architecture 3(1): 19- 36. [In Persian]

Gharehbaglou, M., Farshcian, A.H., and Mohammad Alian, Z. 2016. The Influence and Effects of Social Interaction on Place Creation in Islamic Architecture. Journal of Arts and Humanities Studies 2(8-9): 1- 18. [In Persian]

Gregotti, Vittorrio. Et al. 1992. Contextualism?. Lotus International. (74).

Hashempour. P., Nezhadebrahimi, A., and Yazdani, S. 2018. Applying the contextualism approach in regeneration of historical textures(Case Study: Tabriz SAHEB-AL-AMR Square). Journal of Sustainable Architecture and Urban Design 6(1): 105- 126. [In Persian]

Hooshyar Yousefi, Bahram. 2015. Some Clues about Architectural Identity. Designer Magazine (11): 75- 80. [In Persian]

Hooshyar Yousefi, Bahram., and Chokhachian, Ata. 2015. A Search for the Lost Identity. Designer Magazine (11): 55- 58. [In Persian]

Hojat, Isah. 2012. Tradition and Innovation in Architectural Education. Tehran: University of Tehran Press(UTP). [In Persian]

Islami, Gholamreza. 1998. Endogenous development: A model for the Process of Man-Environment Transaction. unpublished 
PhD Thesis. Heriot-Wat University. Faculty of Environmental Studies. Edinburgh College of Art. Depatment of Architecture. Edinburgh. U.K.

Islami, Seyed Gholamreza. 2011. Lessons on architectural theory. Architecture Department. University of Tehran. [In Persian]

Islami, Seyed Gholam Reza., and Shahinrad, Mahnoosh. 2012. The Principle of Horizontality in Islamic Architecture. Journal of Kimiya-ye-Honar 1(2): 41- 64. [In Persian]

Izadi, Mohammad Saeid. 2019. Reflection of the Growth and Development of Creative Thoughts in Recognizing the Foundations of Iranshahr Urbanization. Journal of Conservation of Historical Area 1(in print queue). [In Persian]

J. Fox, Eric. 2008. Conceptualisttic Perspectives. Western Michigan University. Kalamazoo. Michigan (5): 55- 66.

Jormakka, Kari. 2017. Basics design methods. Birkhäuser.

Masoud, Mohammad., and Beigzadeh Shahraki, Masoud. 2013. Intermediate Buildings in Historical Contexts(Basics of Urban Design and Evaluation Criteria). Tehran: Azarakhsh Publishing. [In Persian]

MirBagheri, S.Mohammad Mehdi. 2014. Art, Religion, Modernity(Speeches in Art Basics). Qom: Publication of Modern Islamic Civilization (affiliated to Institute of Islamic Culture). [In Persian]

Mirzahosseini, M., Soltanzadeh, H., and Alborzi, F. 2019. The Role of German Engineers on Contemporary Iranian Architecture (With Emphasis on the First Pahlavi Period between 1925 and 1941). Journal of Bagh-e Nazar 16(75): 53- 70. [In Persian]

Mirsajadi, S. A., and Farkisch, H. 2017. Recognition of Typology and Effective Physical Factors in Traditional Residential Tissue of Neyshabur. Journal of Researches in Islamic Architecture 4(4): 71- 89. [In Persian]

Molavi, Mohammed. 2018. The Social Approach to Quranic Tafsir as an Effective Driving Force in the Shaping and Prosperity of the New Islamic Civilization. Journal of Iran Futures Studies 2(2): 141- 160. [In Persian]

Mortada, Hisham. 2005. Traditional Islamic principles of built environment. Translated by Meshkini and Habibi. Tehran: Iranian Center for Urban Studies and Research. [In Persian]

Mozaffari, Ali. 2014. Forming National Identity in Iran: The Idea of Homeland Derived from Ancient Persian and Islamic Imaginations of Place. Visual Culture: Art Theory \& Aesthetics. London: I.B.Tauris \& Co Ltd.

Nasr, Seyyed Hossein. 1990. Islamic art spirituality. Translated by Rahim Ghasemian. Tehran: Hekmat Publishing. [In Persian]

Naghavi, Pooyan., and Mazaherian, Hamed. 2019. Analysis of Contemporary Theories When Encountering the Context in Architectural Design. Journal of Bagh-e Nazar 16(74): 69- 80. [In Persian]

Naghizadeh, Mohammad. 2002. The Influence of Architecture and the City on Cultural Values. Journal of Honar-Ha-YeZiba(Memari-va-Shahrsazi) 11(11): 62- 76. [In Persian]

Naghizadeh, Mohammad. 2014. Iranian Garden from Imagination to Reality. Tehran: Iranian Student Book Agency(ISBA) [In Persian]

Naghizadeh, Mohammad. 2015. The "Quranic Teaching" and the "Ideal Islamic City". Journal of Researches in Islamic Architecture 3(3): 46- 64. [In Persian]

Nezh Edebrahimi, Ahad., and Farshchian, Amir Hossein. 2014. The Relationship between Ethics and Technology in Architecture for the Islamic Community. Journal of Researches in Islamic Architecture 2(3): 114- 131. [In Persian]

Noghrekar, A., Hamzenejad, M., and Forouzande, E. 2009. Eternity Secret of Architectural Works (In Modernism, Post Modernism and More Inclusive View). Journal of Bagh-e Nazar 6(12): 31- 44. [In Persian]

Pallasma, Juhani. 2013. The thinking hand : existential and embodied wisdom in arthitecture. Translated by Ali Akbari. Tehran: Parham Naghsh Publishing.

Pirbabaei, M.T., Gharehbaglou, M., and Alinam, Z. 2016. An investigation on the effects of individual factors in process-oriented study of place attachment with a cognitive psychological approach (Case study: The Gharebaghis' neighborhood of Tabriz). Journal of Honar-Ha-Ye-Ziba(Memari-va-Shahrsazi) 21(2): 55- 68. [In Persian]

Pirbabaei, Mohammad Taghi., and Molaei, Asghar. 2016. The Contextual, Regional and Urban Design of the Path of Imam Reza's Journey to Iran. Journal of Razavi Culture 4(16): 101-142. [In Persian]

Pirnia, Mohammad Karim. 2004. Iranian Architecture Stylistics. Tehran: Soroush Danesh. [In Persian]

PourAhmad, A., and Mousavi, S. 2011. The social nature of Islamic city. Journal of Studies on Iranian Islamic city. 1(2): 1- 12. [In Persian]

Pourjafar, M.R., Ranjbar, E., and Amirkhani, A. 2008. The Quality of Traditional and Ethical Design Ideas Crystallizing in the Works of Contemporary Japanese Architects. Journal of Bagh-e Nazar 5(9): 3- 22. [In Persian]

Pourjafar, M.R., Pourjafar, A., and Safdari, S. 2015. Various Types of Islamic City and Pointing Out to Defining the Major Aspects of Ideal Islamic City. Journal of Researches in Islamic Architecture 3(3): 1- 17. [In Persian]

Qayyoomi, Mehrdad. 2011. Speeches in the basics and history of architecture and art. Tehran: Scientific and Cultural Publishing Company. [In Persian]

Rapoport, A. 1969. House Form and Culture. New York: Prentice-Hall Inc.

Raeesi, Mohammad Mannan. 2017. Seeking the cause of identity crisis in contemporary architecture and urbanism of Iran with emphasis on triple of vision and value and action. Journal of Honar-Ha-Ye-Ziba(Memari-va-Shahrsazi) 21(4): 63- 74. [In Persian]

Rezaei, Mahmud. 2014. Design Analytica: Reviewing Theories and Concepts in Contemporary. Tehran: Islamic Azad University, Central Tehran Branch Publishing. [In Persian]

Sayyadi, S.E., Maddahi, S.M., and Mohammadpour, A. 2011. Sustainable Architecture. Tehran: Lutos Publishing. [In Persian]

Seddigh, R. 2000. Meta-Analysis of Studies in the Field of Social Pathology in Iran. Journal of Social Sciences Letter 15(15): 67103. [In Persian]

Shahidi, M.SH., Bemanian, M.R., and Yalpanian, M. 2008. The Role of Research in Architectural Design Training. Journal of Hoviate Shahr 2(2): 81- 92. [In Persian]

$$
\text { فرهنحِ معمارى و شهرسازى اسلامى - سال ينجم، شماره اول - بهار و تابستان } 99
$$


بازشناسى الحوها و رويههاى معمارى زمينهًَا در انديشه و شهرهاى اسلامى در عصر جهانىسازى

Shahteimori, Yalda., and Mazaherian, Hamed. 2013. Design Guidelines for New Constructions in Historic Context. Journal of Honar-Ha-Ye-Ziba(Memari-va-Shahrsazi) 17(4): 1- 15. [In Persian]

Taban, Mohsen., Hashemi Demneh, L.S., Pourjafar, M.R., Pourmand, H., and Zabihi, H. 2011. The social nature of Islamic city. Journal of Studies on Iranian Islamic city. 1(3): 11- 20. [In Persian]

Tabatabaie, Mohammad Hossein. 1984. Tafsir Al-Mizan. Translated by Mohammad Bagher Hamedani. Qom: Raja Publishing. [In Persian]

Taghvaie, Vida. 2016. From Theoretical to Theoretical Foundations, in Art and Architecture. Tehran: Technical \& Vocational University. [In Persian]

Tavallaei, Novin. 2002. Contextualism in Urban Planning. Journal of Honar-Ha-Ye-Ziba(Memari-va-Shahrsazi) (10): 34- 43. [In Persian]

Trancik, Roger. 1986. Finding lost Space: The Theories of Spatial Urban Design. New York: Van Nostrand.

Lim, W. 2004. Architecture, Art, Identity: Is There Life in Singapore After Tabula Rasa?. in Identity Research/Research Papers: Architecture and Identity (Sponsored by Volkswagen Stiftung and Berlin University of Technology, architectureidentity.de).

Zarezadeh, M., Daneshmand, S., and AliAbadi, M. 2015. How to intervene with a field-oriented manner in the sustainability of historical contexts using Space Syntax method. Journal of Sustainable Architecture and Urban Design 3(1): 75- 90. [In Persian] 